Supporting Information

\title{
Cumulene Wires Display Increasing Conductance with Increasing Length
}

Yaping Zang ${ }^{1 \star \dagger}$, Tianren $\mathrm{Fu}^{2 \ddagger}$, Qi Zou*2,3, Fay $\mathrm{Ng}^{2}$, Hexing $\mathrm{Li}^{3}$, Michael L. Steigerwald ${ }^{2}$, Colin Nuckolls*2, Latha Venkataraman*1,2

${ }^{1}$ Department of Applied Physics and Applied Mathematics, Columbia University, New York, New York 10027, United States

${ }^{2}$ Department of Chemistry, Columbia University, New York, New York 10027, United States

${ }^{3}$ Shanghai Key Laboratory of Materials Protection and Advanced Materials in Electric Power, Shanghai University of Electric Power, Shanghai 200090, China

$\$$ These authors contributed equally.

$\dagger$ Present Address: CAS Key Laboratory of Organic Solids, Institute of Chemistry, Chinese Academy of Sciences, Beijing 100190, China.

Table of Contents:

1. Additional Data

2. Synthetic Details

3. NMR Spectra 


\section{Additional Data}
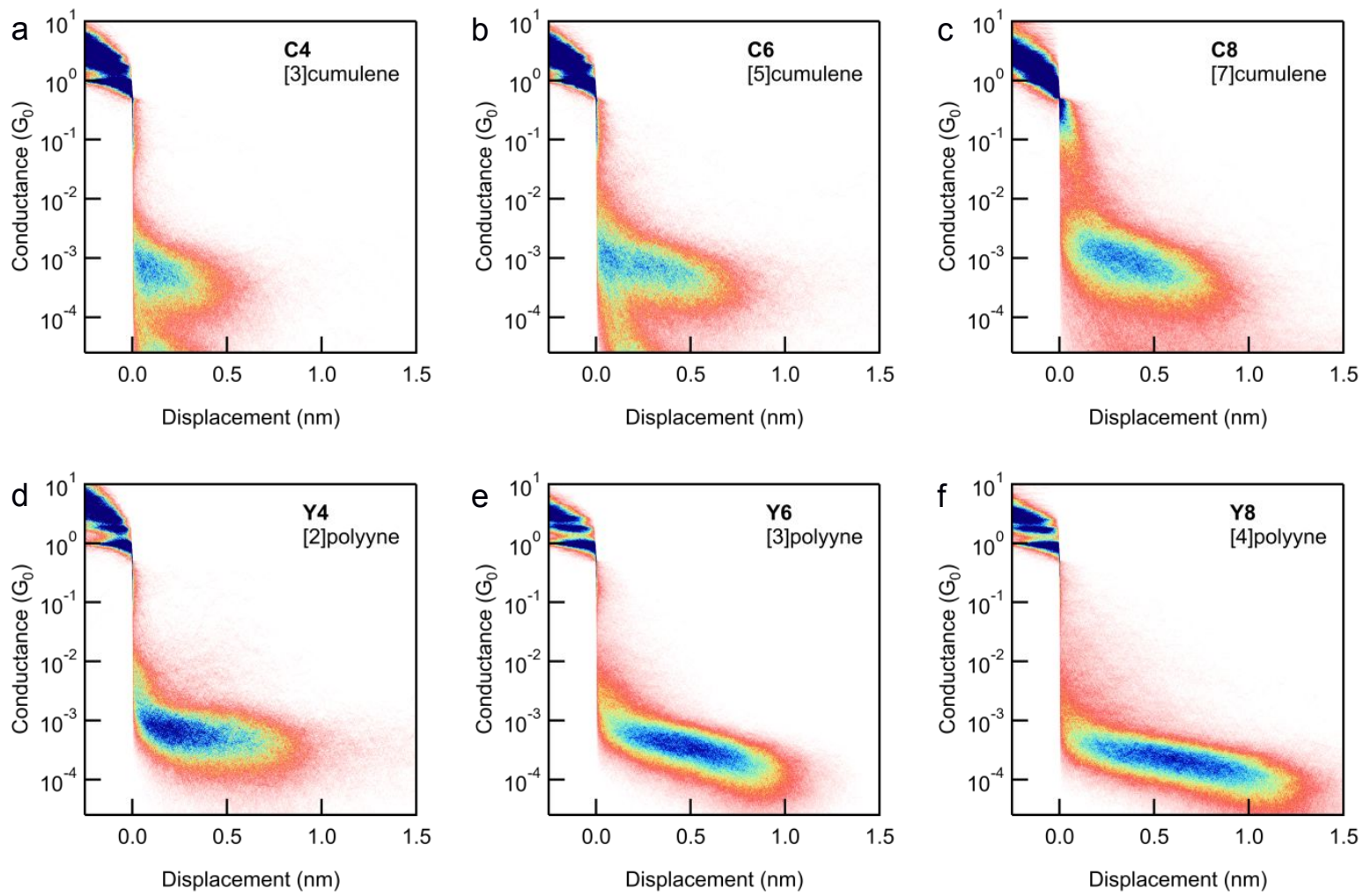

Figure S1. Two-dimensional conductance histograms of (a) C4, (b) C6, (c) C8, (d) Y4, (e) Y6 and (f) Y8 in 1,2,4-trichlorobenzene (TCB) solution. The corresponding one-dimensional histograms are in the Figure $1 \mathrm{~b}$ and $1 \mathrm{c}$. 

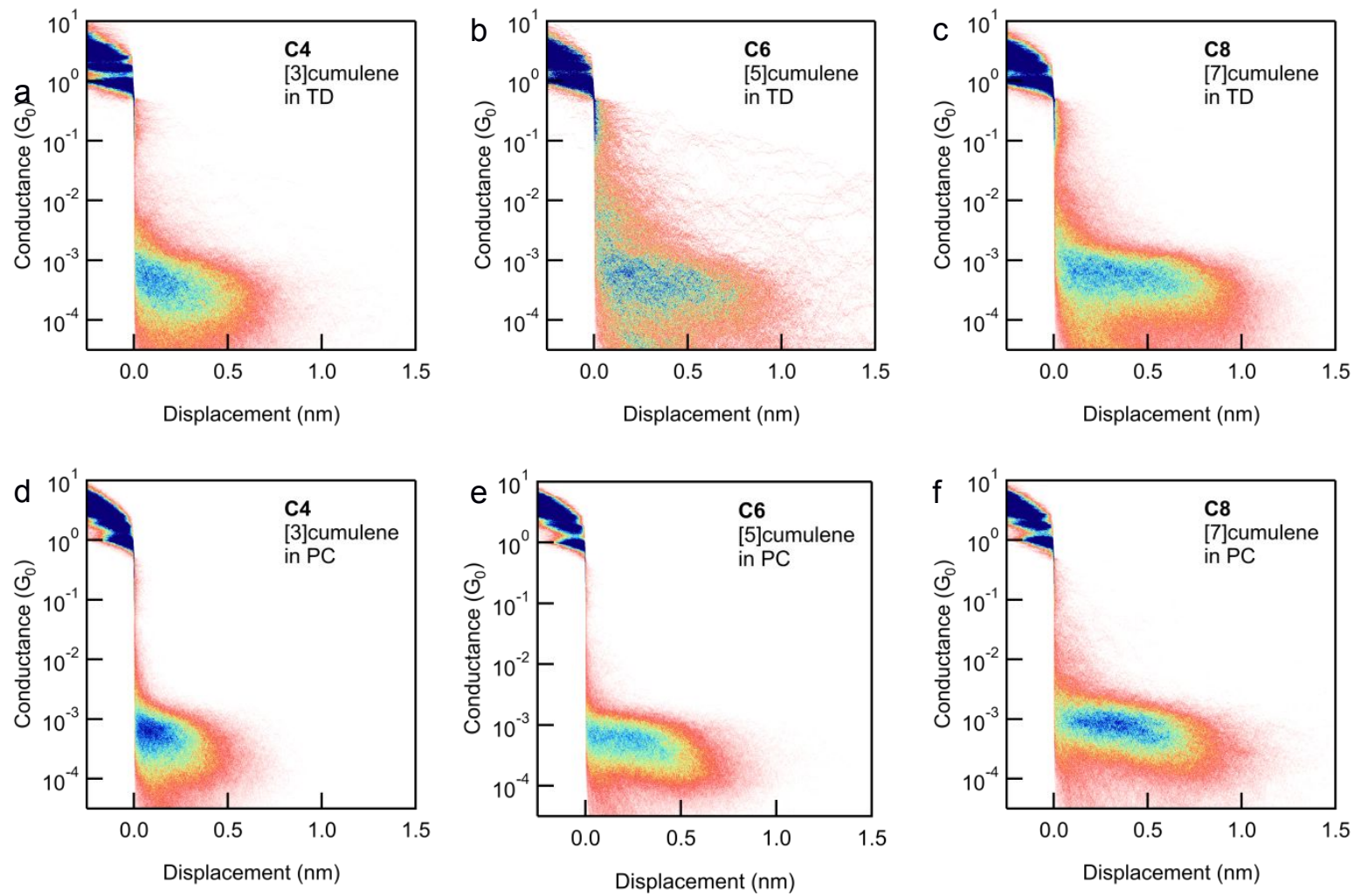

Figure S2. Two-dimensional conductance histograms of (a) C4, (b) C6 and (c) C8 in $n$-tetradecane (TD) and (d) C4, (e) $\mathbf{C 6}$ and (f) $\mathbf{C 8}$ in propylene carbonate (PC). The corresponding onedimensional histograms are in the Figure $3 a$ and $3 b$.
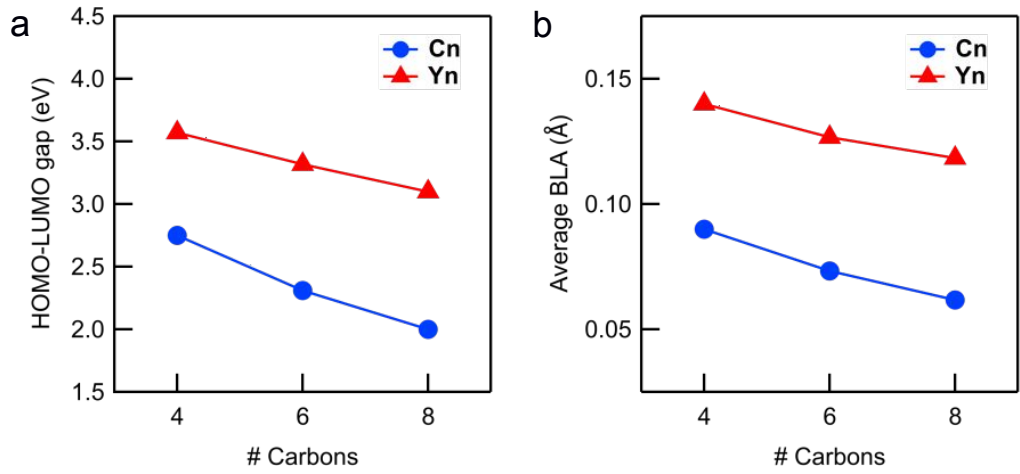

Figure S3. (a) The theoretical HOMO-LUMO gap for cumulenes (Cn-series) and polyynes (Ynseries). (b) The average bond length alternation (BLA) values for cumulenes and polyynes. The average BLA is the difference between the average bond length of bonds with odd bond indices and even bond indices. 


\section{Synthetic Details}

\subsection{General}

All reactions were performed in oven-dried round bottom flasks, unless otherwise noted. The flasks were fitted with Teflon magnetic stir bar, rubber septa and reactions were conducted under a positive pressure of nitrogen, unless otherwise noted. Anhydrous and anaerobic solvents were obtained from Schlenk manifold with purification columns packed with activated alumina and supported copper catalyst (Glass Contour, Irvine, CA). For the synthesis of compounds C6 and C8, the post-treatment procedures were carried out in Aldrich ${ }^{\circledR}$ AtmosBag filled with nitrogen. Automated flash chromatography was performed using a Teledyne Isco Combiflash $\mathrm{R}_{\mathrm{f}} 200$ and Redisep $\mathrm{R}_{\mathrm{f}}$ Silica/Alumina columns.

Materials. All chemicals were purchased from commercial sources and used without further purification unless otherwise specified. The syntheses of compounds $\mathbf{Y 4},{ }^{1} \mathbf{Y 6},{ }^{2} \mathbf{Y 8}^{2}$ and $\mathbf{C} 4^{3}$ were based on the literature procedures, respectively.

Instrumentation. ${ }^{1} \mathrm{H} \mathrm{NMR}$ and ${ }^{13} \mathrm{C}$ NMR spectra in deuterated solvents were recorded on Brucker DRX400 (400 MHz) or a Bruker DMX500 (500 MHz) spectrometer. Chemical shifts for protons are reported in parts per million downfield from tetramethylsilane and are referenced to residual protium in the NMR solvents $\left(\mathrm{CDCl}_{3}: \delta 7.26 ; \mathrm{C}_{2} \mathrm{D}_{2} \mathrm{Cl}_{4}: \delta 6.00 ; \mathrm{CD}_{2} \mathrm{Cl}_{2}: \delta 5.32\right)$. Chemical shifts for carbon are reported in parts per million downfield from tetramethylsilane and are referenced to the carbon resonances of the solvent $\left(\mathrm{CDCl}_{3}: \delta 77.0 ; \mathrm{C}_{2} \mathrm{D}_{2} \mathrm{Cl}_{4}: \delta 74.0 ; \mathrm{CD}_{2} \mathrm{Cl}_{2}: \delta\right.$ 53.8). Data are represented as follows: chemical shift, multiplicity ( $\mathrm{s}=$ singlet, $\mathrm{d}=$ doublet, $\mathrm{t}=$ triplet, $\mathrm{q}=$ quartet, $\mathrm{m}=$ multiplet), coupling constants in Hertz, and integration.

High-resolution mass spectrometry (HRMS) was recorded on a Waters XEVO G2-XS QTOF spectrometer with dichloromethane as solvent. 


\subsection{Synthetic Procedures}
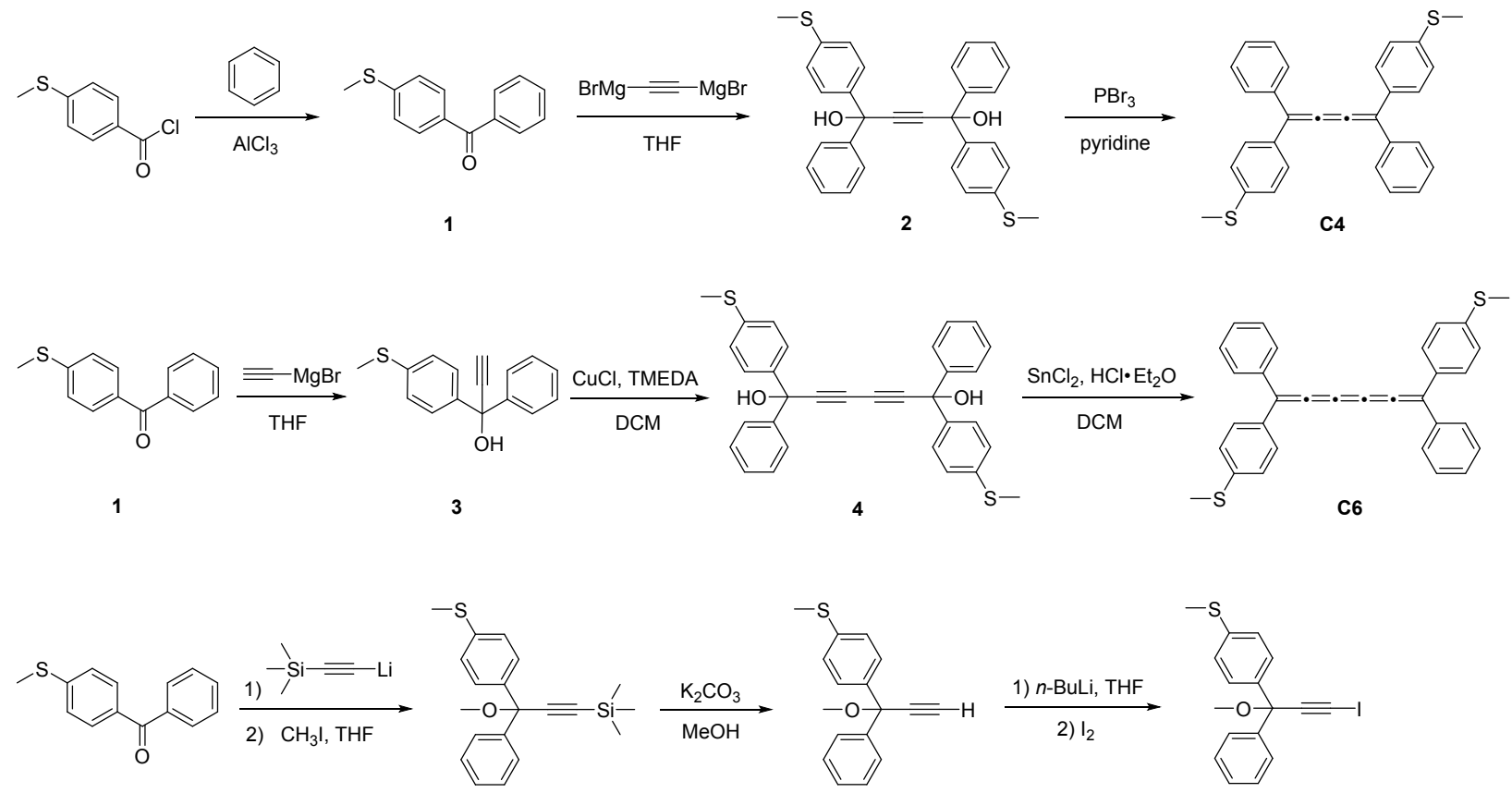

1

5

6

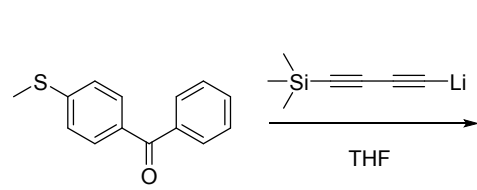

1

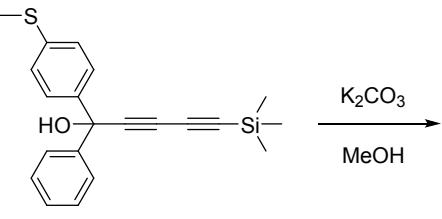

8
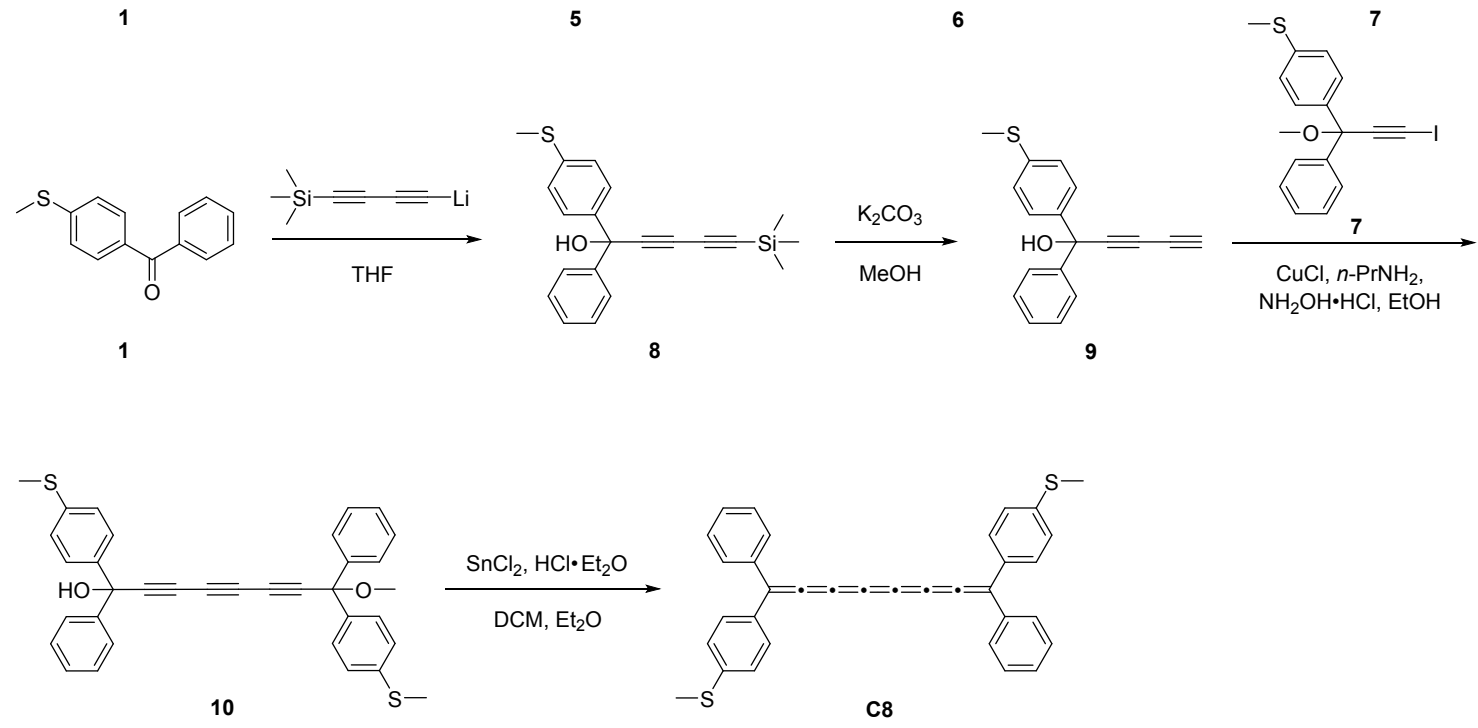

Scheme S1. Synthetic route of cumulene compounds.

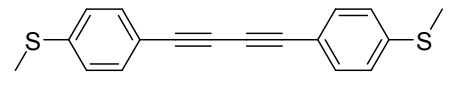

Y4

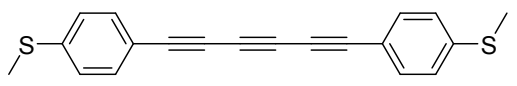

Y6

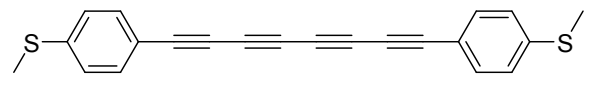

Y8

Scheme S2. Structures of polyyne compounds. 


\subsubsection{Synthesis of $\boldsymbol{C 4}$}<smiles>CSc1ccc(C(=O)c2ccccc2)cc1</smiles>

Synthesis of 4-methylthio-benzophenone (1). Under nitrogen atmosphere, to the mixture of $\mathrm{AlCl}_{3}(0.784 \mathrm{~g}, 5.88 \mathrm{mmol})$ and 4-(methylthio)benzoyl chloride (0.548 g, $\left.2.94 \mathrm{mmol}\right)$, benzene $(5.0 \mathrm{~mL})$ was added dropwise over a $10 \mathrm{~min}$ period at $0{ }^{\circ} \mathrm{C}$, with stirring. The cooling bath was removed and the mixture was stirred at room temperature for $5 \mathrm{~h}$. The resulting solution was poured into icy $1 \mathrm{M} \mathrm{HCl}$ aqueous solution $(40.0 \mathrm{~mL})$, extracted with dichloromethane (20.0 $\mathrm{mL} \times 3)$, combined organic layers were washed with water $(30.0 \mathrm{~mL} \times 2)$ and dried over anhydrous $\mathrm{Na}_{2} \mathrm{SO}_{4}$. Then the mixture was filtered through a pad of silica gel and eluted with dichloromethane (50.0 mL), and concentrated to afford the compound $\mathbf{1}(0.625 \mathrm{~g}, 93 \%)$ as an off-white solid. ${ }^{1} \mathrm{H}$ NMR (400 MHz, $\left.\mathrm{CDCl}_{3}, 298 \mathrm{~K}\right) \delta(\mathrm{ppm}): 2.54\left(\mathrm{~s}, 3 \mathrm{H},-\mathrm{SCH}_{3}\right), 7.30(\mathrm{~d}, J 8.0 \mathrm{~Hz}, 2 \mathrm{H}$, benzene-H), 7.46-7.50 (m, 2H, benzene-H), 7.56-7.60 (m, 1H, benzene-H), 7.74-7.78 (m, 4H, benzene-H). ${ }^{13} \mathrm{C}$ NMR (126 MHz, $\left.\mathrm{CDCl}_{3}, 298 \mathrm{~K}\right) \delta$ (ppm): 14.77, 124.75, 128.19, 129.75, 130.58, 132.12, 133.55, 137.78, 145.23, 195.73. HRMS (ASAP+, $m / z)$ : $[\mathrm{M}+\mathrm{H}]^{+}$calcd. for $\mathrm{C}_{14} \mathrm{H}_{13} \mathrm{OS}, 229.0687$; found, 229.0678 .

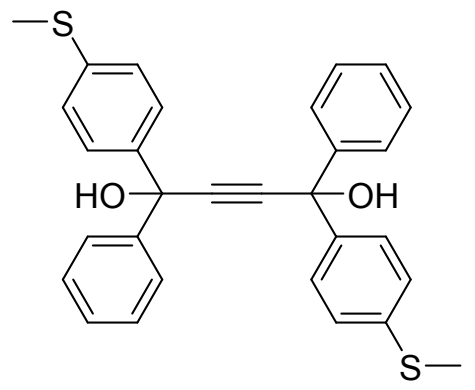

Synthesis of 1,4-bis(4-(methylthio)phenyl)-1,4-diphenylbut-2-yne-1,4-diol (2). Under nitrogen atmosphere, ethynylmagnesium bromide (5.44 mL, $2.72 \mathrm{mmol}, 0.5 \mathrm{M}$ in THF) was added 
dropwise to the solution of ethylmagnesium bromide $\left(1.0 \mathrm{~mL}, 3.0 \mathrm{mmol}, 3.0 \mathrm{M}\right.$ in $\left.\mathrm{Et}_{2} \mathrm{O}\right)$ in anhydrous THF ( $4.4 \mathrm{~mL}$ ) over a $10 \mathrm{~min}$ period at room temperature, with stirring. After completing the addition, the reaction mixture was refluxed for $2 \mathrm{~h}$ to give a product which was white bis(bromomagnesium)acetylene. After cooling to room temperature, the solution of compound $\mathbf{1}$ $(1.242 \mathrm{~g}, 5.44 \mathrm{mmol})$ in anhydrous THF $(3.6 \mathrm{~mL})$ was added dropwise over a $10 \mathrm{~min}$ period. Then the mixture was refluxed again for $3.5 \mathrm{~h}$. After cooling to room temperature, the solution was poured into icy $1 \mathrm{M} \mathrm{HCl}$ aqueous solution $(50.0 \mathrm{~mL})$, extracted with ethyl acetate $(30.0 \mathrm{~mL} \times 3)$, combined organic layers were washed with saturated $\mathrm{NaHCO}_{3}$ solution $(30.0 \mathrm{~mL})$ and saturated $\mathrm{NaCl}$ solution $(30.0 \mathrm{~mL})$, and dried over anhydrous $\mathrm{Na}_{2} \mathrm{SO}_{4}$, filtered, and concentrated. The residue was purified by column chromatography ( $24 \mathrm{~g}$ Redisep $\mathrm{R}_{\mathrm{f}}$ Silica) using a gradient from $0 \%$ to $40 \%$ ethyl acetate/hexanes to give the compound $2(1.052 \mathrm{~g}, 80 \%)$ as a white solid. ${ }^{1} \mathrm{H}$ NMR $\left(400 \mathrm{MHz}, \mathrm{CDCl}_{3}, 298 \mathrm{~K}\right) \delta(\mathrm{ppm}): 2.46\left(\mathrm{~s}, 6 \mathrm{H},-\mathrm{SCH}_{3}\right), 2.86(\mathrm{~s}, 2 \mathrm{H},-\mathrm{OH}), 7.19(\mathrm{~d}, J 8.0 \mathrm{~Hz}, 4 \mathrm{H}$, benzene-H), 7.27-7.34 (m, 6H, benzene-H), 7.49 (d, $J 8.0 \mathrm{~Hz}, 4 \mathrm{H}$, benzene-H), 7.57 (d, $J 8.0 \mathrm{~Hz}$, 4H, benzene-H). ${ }^{13} \mathrm{C} \mathrm{NMR}\left(101 \mathrm{MHz}, \mathrm{CDCl}_{3}, 298 \mathrm{~K}\right) \delta(\mathrm{ppm}): 15.65,74.29,89.86,125.90,126.26$, 126.49, 127.89, 128.37, 138.26, 141.52, 144.50. HRMS (ASAP+, m/z): $[\mathrm{M}]^{+}$calcd. for $\mathrm{C}_{30} \mathrm{H}_{26} \mathrm{O}_{2} \mathrm{~S}_{2}, 482.1374$; found, 482.1372.

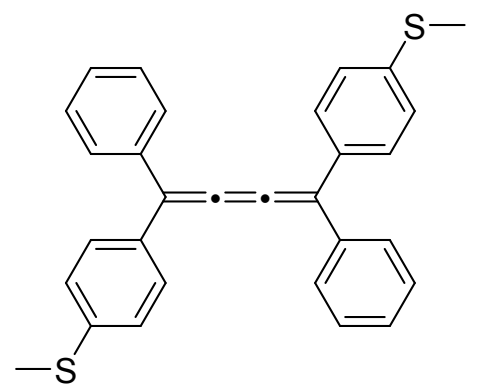

Synthesis of 1,4-bis(4-(methylthio)phenyl)-1,4-diphenylbuta-1,2,3-triene (C4). Under nitrogen atmosphere, to the solution of compound $2(0.150 \mathrm{~g}, 0.31 \mathrm{mmol})$ in anhydrous pyridine $(2.7 \mathrm{~mL})$, phosphorus tribromide $(0.09 \mathrm{~mL}, 0.93 \mathrm{mmol})$ was added dropwise over a 5 min period at room 
temperature and stirred for another $2 \mathrm{~h}$. After cooling to $0{ }^{\circ} \mathrm{C}$, water $(15.0 \mathrm{~mL})$ was added dropwise to quench the reaction. The resulting yellow mixture was extracted with dichloromethane (20.0 $\mathrm{mL} \times 3)$, combined organic layers were washed with saturated $\mathrm{NaHCO}_{3}$ solution $(20.0 \mathrm{~mL})$ and dried over anhydrous $\mathrm{Na}_{2} \mathrm{SO}_{4}$, filtered, and concentrated. The residue was purified by column chromatography (24 g Redisep $\mathrm{R}_{\mathrm{f}}$ Alumina) using hexanes to give the crude product as a red solid. Recrystallization from ethyl acetate and hexanes (1:2, v/v) afforded the compound C4 (0.062 g, $44 \%$ ) as a yellow solid that was isolated as the $2: 1$ mixture of $E$ and $Z$ isomers. ${ }^{1} \mathrm{H}$ NMR (400 $\left.\mathrm{MHz}, \mathrm{CD}_{2} \mathrm{Cl}_{2}, 298 \mathrm{~K}\right) \delta(\mathrm{ppm}): 2.52\left(\mathrm{~s}, 2 \mathrm{H},-\mathrm{SCH}_{3}\right), 2.54\left(\mathrm{~s}, 4 \mathrm{H},-\mathrm{SCH}_{3}\right), 7.24-7.28(\mathrm{~m}, 4 \mathrm{H}$, benzene-H), 7.32-7.43 (m, 6H, benzene-H), 7.47-7.50 (m, 4H, benzene- $\mathrm{H})$, 7.53-7.57 (m, 4H, benzene-H). ${ }^{13} \mathrm{C}$ NMR (101 MHz, $\left.\mathrm{CD}_{2} \mathrm{Cl}_{2}, 298 \mathrm{~K}\right) \delta(\mathrm{ppm}): 15.63,122.17,126.27,126.29,128.40$, 128.83, 128.86, 129.66, 129.69, 129.91, 129.95, 135.69, 135.76, 138.94, 139.01, 139.42, 150.75. HRMS (ASAP+, m/z): [M] calcd. for $\mathrm{C}_{30} \mathrm{H}_{24} \mathrm{~S}_{2}, 448.1319$; found, 448.1320 .

\subsubsection{Synthesis of $\mathbf{C 6}$}

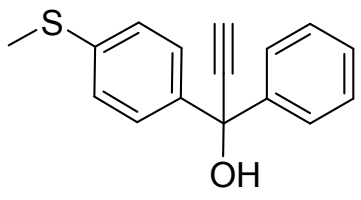

Synthesis of 1-(4-(methylthio)phenyl)-1-phenylprop-2-yn-1-ol (3). Under nitrogen atmosphere, ethynylmagnesium bromide (5.60 $\mathrm{mL}, 2.80 \mathrm{mmol}, 0.5 \mathrm{M}$ in THF) was added dropwise to a solution of compound $1(0.559 \mathrm{~g}, 2.45 \mathrm{mmol})$ in anhydrous THF $(5.0 \mathrm{~mL})$ over a $15 \mathrm{~min}$ period at room temperature, with stirring. After completing the addition, the solution was stirred for $6 \mathrm{~h}$ at room temperature. Then the solution was poured into icy $1 \mathrm{M} \mathrm{HCl}$ aqueous solution $(40.0 \mathrm{~mL})$, extracted with ethyl acetate $(20.0 \mathrm{~mL} \times 3)$, combined organic layers were washed with saturated $\mathrm{NaHCO}_{3}$ solution $(30.0 \mathrm{~mL})$ and saturated $\mathrm{NaCl}$ solution $(30.0 \mathrm{~mL})$, and dried over anhydrous 
$\mathrm{Na}_{2} \mathrm{SO}_{4}$, filtered, and concentrated. The residue was purified by column chromatography ( $24 \mathrm{~g}$ Redisep $\mathrm{R}_{\mathrm{f}}$ Silica) using a gradient from $0 \%$ to $35 \%$ ethyl acetate/hexanes to give the compound $\mathbf{3}$ (0.498 g, 80\%) as a pink liquid. ${ }^{1} \mathrm{H}$ NMR (400 MHz, $\left.\mathrm{CDCl}_{3}, 298 \mathrm{~K}\right) \delta(\mathrm{ppm}): 2.46\left(\mathrm{~s}, 3 \mathrm{H},-\mathrm{SCH}_{3}\right)$, $2.78(\mathrm{~s}, 1 \mathrm{H},-\mathrm{OH}), 2.88(\mathrm{~s}, 1 \mathrm{H},-\mathrm{C} \equiv \mathrm{CH}), 7.21(\mathrm{~d}, J 8.0 \mathrm{~Hz}, 2 \mathrm{H}$, benzene-H), 7.27-7.30 (m, 1H, benzene-H), 7.32-7.36 (m, 2H, benzene-H), $7.52(\mathrm{~d}, J 12.0 \mathrm{~Hz}, 2 \mathrm{H}$, benzene-H), 7.59-7.61 (m, 2H, benzene-H). ${ }^{13} \mathrm{C}$ NMR (101 MHz, $\left.\mathrm{CDCl}_{3}, 298 \mathrm{~K}\right) \delta(\mathrm{ppm}):$ 15.65, 73.98, 75.56, 86.19, 125.90, 126.21, 126.49, 127.92, 128.32, 138.30, 141.27, 144.24. HRMS (ASAP+, m/z): [M-OH] $]^{+}$calcd. for $\mathrm{C}_{16} \mathrm{H}_{13} \mathrm{~S}, 237.0732$; found, 237.0742 .

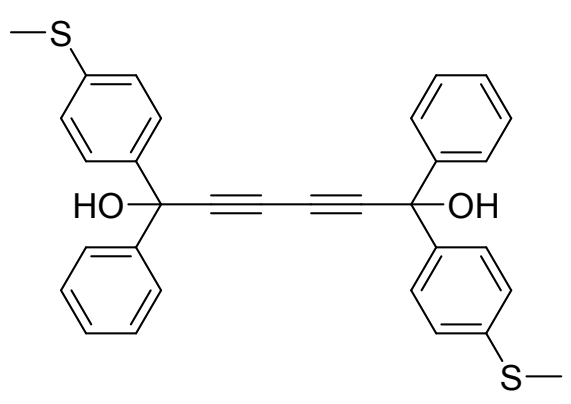

Synthesis of 1,6-bis(4-(methylthio)phenyl)-1,6-diphenylhexa-2,4-diyne-1,6-diol (4). Hay catalyst was prepared by stirring the mixture of TMEDA $(1.18 \mathrm{~mL}, 7.84 \mathrm{mmol})$ and $\mathrm{CuCl}(0.388$ g, $3.92 \mathrm{mmol})$ in dichloromethane $(45.0 \mathrm{~mL})$ for $30 \mathrm{~min}$ at room temperature. Then Hay catalyst was added to the solution of compound $\mathbf{3}(0.499 \mathrm{~g}, 1.96 \mathrm{mmol})$ in dichloromethane $(45.0 \mathrm{~mL})$ and stirred for $8 \mathrm{~h}$ at room temperature open to air. The organic phase was washed with saturated $\mathrm{NH}_{4} \mathrm{Cl}$ solution $(30.0 \mathrm{~mL} \times 2)$ and saturated $\mathrm{NaCl}$ solution $(30.0 \mathrm{~mL})$, and dried over anhydrous $\mathrm{Na}_{2} \mathrm{SO}_{4}$. Then the mixture was filtered through a pad of silica gel and eluted with dichloromethane (100.0 mL), and concentrated to afford the compound $4(0.493 \mathrm{~g}, 99 \%)$ as a pink solid. ${ }^{1} \mathrm{H}$ NMR $\left(400 \mathrm{MHz}, \mathrm{CDCl}_{3}, 298 \mathrm{~K}\right) \delta(\mathrm{ppm}): 2.46\left(\mathrm{~s}, 6 \mathrm{H},-\mathrm{SCH}_{3}\right), 2.81(\mathrm{~s}, 2 \mathrm{H},-\mathrm{OH}), 7.21(\mathrm{~d}, J 8.0 \mathrm{~Hz}, 4 \mathrm{H}$, benzene-H), 7.27-7.36 (m, 6H, benzene-H), 7.46 (d, $J 8.0 \mathrm{~Hz}, 4 \mathrm{H}$, benzene- $\mathrm{H}), 7.53-7.56(\mathrm{~m}, 4 \mathrm{H}$, benzene-H). ${ }^{13} \mathrm{C}$ NMR (101 MHz, $\left.\mathrm{CDCl}_{3}, 298 \mathrm{~K}\right) \delta(\mathrm{ppm}): 15.61,71.16,74.66,82.62,126.02$, 
126.24, 126.57, 128.16, 128.43, 138.68, 140.66, 143.69. HRMS (ASAP+, m/z): [M] $]^{+}$calcd. for $\mathrm{C}_{32} \mathrm{H}_{26} \mathrm{O}_{2} \mathrm{~S}_{2}, 506.1374$; found, 506.1376.

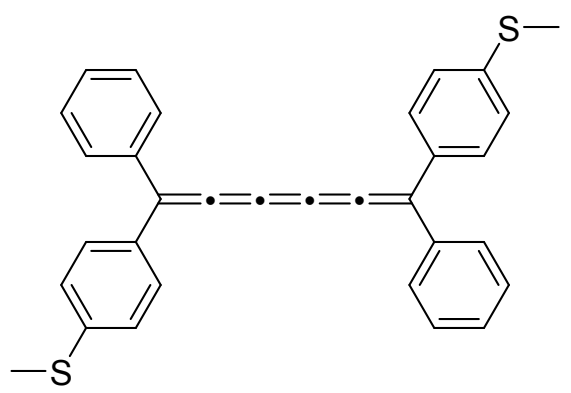

Synthesis of 1,6-bis(4-(methylthio)phenyl)-1,6-diphenylhexa-1,2,3,4,5-pentaene (C6). Under

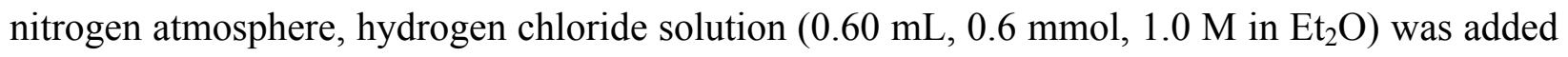
to the mixture of compound $4(0.051 \mathrm{~g}, 0.1 \mathrm{mmol})$ and anhydrous $\mathrm{SnCl}_{2}(0.076 \mathrm{~g}, 0.4 \mathrm{mmol})$ in degassed dichloromethane $(5.0 \mathrm{~mL})$ over a $10 \min$ period at $-78^{\circ} \mathrm{C}$ and stirred for another $50 \mathrm{~min}$ at $-78{ }^{\circ} \mathrm{C}$. Then the solution was filtered through a plug of basic alumina oxide and eluted with degassed dichloromethane $(16.0 \mathrm{~mL})$ under nitrogen atmosphere. Degassed hexanes $(4.0 \mathrm{~mL})$ was added to the eluent and reduced to around $7 \mathrm{~mL}$ in vacuum at $30^{\circ} \mathrm{C}$. The resulting suspension was kept at $-20^{\circ} \mathrm{C}$ for $1 \mathrm{~h}$, filtered and washed with diethyl ether $(2.0 \mathrm{~mL})$ to yield the compound $\mathbf{C 6}$ $(0.024 \mathrm{~g}, 51 \%)$ as a red solid that was isolated as the $1: 1$ mixture of $E$ and $Z$ isomers. ${ }^{1} \mathrm{H}$ NMR $\left(500 \mathrm{MHz}, \mathrm{C}_{2} \mathrm{D}_{2} \mathrm{Cl}_{4}, 298 \mathrm{~K}\right) \delta(\mathrm{ppm}): 2.56\left(\mathrm{~s}, 3 \mathrm{H},-\mathrm{SCH}_{3}\right), 2.57\left(\mathrm{~s}, 3 \mathrm{H},-\mathrm{SCH}_{3}\right), 7.28-7.30(\mathrm{~m}, 4 \mathrm{H}$, benzene- $\mathrm{H})$, 7.39-7.48 (m, 6H, benzene- $\mathrm{H})$, 7.54-7.56 (m, 4H, benzene- $\mathrm{H})$, 7.60-7.62 (m, 4H, benzene-H). ${ }^{13} \mathrm{C}$ NMR $\left(126 \mathrm{MHz}, \mathrm{C}_{2} \mathrm{D}_{2} \mathrm{Cl}_{4}, 320 \mathrm{~K}\right) \delta(\mathrm{ppm}): 15.68,123.98,126.42,128.69,128.72$, 129.41, 129.63, 135.05, 138.03, 139.85, 148.06. HRMS (ESI+, m/z): $[\mathrm{M}]^{+}$calcd. for $\mathrm{C}_{32} \mathrm{H}_{24} \mathrm{~S}_{2}$, 472.1319; found, 472.1324 . 


\subsubsection{Synthesis of $\boldsymbol{C 8}$}

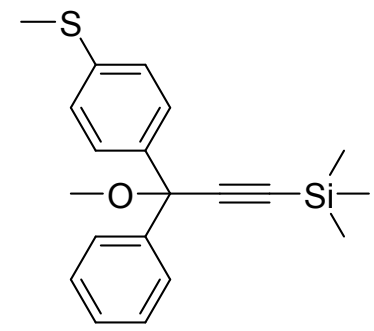

\section{Synthesis of (3-methoxy-3-(4-(methylthio)phenyl)-3-phenylprop-1-yn-1-yl)trimethylsilane}

(5). Under nitrogen atmosphere, $n$-butyl lithium $(1.38 \mathrm{~mL}, 3.44 \mathrm{mmol}, 2.5 \mathrm{M}$ in hexane) was added dropwise to the solution of trimethylsilylacetylene $(0.67 \mathrm{~mL}, 4.86 \mathrm{mmol})$ in anhydrous THF $(6.0$ $\mathrm{mL}$ ) at $-78^{\circ} \mathrm{C}$ over a 6 min period, with stirring. The mixture was stirred for $1 \mathrm{~h}$ at $-78{ }^{\circ} \mathrm{C}$ and then the reaction mixture was quenched with the solution of compound $1(0.740 \mathrm{~g}, 3.24 \mathrm{mmol})$ in anhydrous THF $(12.0 \mathrm{~mL})$. The cooling bath was removed and the solution was stirred for $3 \mathrm{~h}$ at room temperature, before iodomethane $(1.21 \mathrm{~mL}, 19.44 \mathrm{mmol})$ was added. After completing the addition, the solution was stirred for $16 \mathrm{~h}$ at room temperature. Then the solution was poured into saturated $\mathrm{NH}_{4} \mathrm{Cl}$ aqueous solution $(50.0 \mathrm{~mL})$, extracted with ethyl acetate $(30.0 \mathrm{~mL} \times 3)$, combined organic layers were washed with saturated $\mathrm{NaCl}$ solution $(30.0 \mathrm{~mL})$, and dried over anhydrous

$\mathrm{Na}_{2} \mathrm{SO}_{4}$, filtered, and concentrated. The residue was purified by column chromatography ( $24 \mathrm{~g}$ Redisep $\mathrm{R}_{\mathrm{f}}$ Silica) using a gradient from $0 \%$ to $10 \%$ ethyl acetate/hexanes to give the compound 5 $(1.070 \mathrm{~g}, 97 \%)$ as a light-pink liquid. ${ }^{1} \mathrm{H} \mathrm{NMR}\left(400 \mathrm{MHz}, \mathrm{CDCl}_{3}, 298 \mathrm{~K}\right) \delta(\mathrm{ppm}): 0.25$ (s, 9H, $\left.\mathrm{Si}\left(\mathrm{CH}_{3}\right)_{3}\right), 2.46\left(\mathrm{~s}, 3 \mathrm{H},-\mathrm{SCH}_{3}\right), 3.33$ (s, 3H, $\left.-\mathrm{OCH}_{3}\right), 7.19$ (d, $J 12.0 \mathrm{~Hz}, 2 \mathrm{H}$, benzene-H), 7.227.24 (m, 1H, benzene-H), 7.30 (t, J 6.0 Hz, 2H, benzene-H), 7.45 (d, J 8.0 Hz, 2H, benzene-H), $7.53\left(\mathrm{~d}, J 8.0 \mathrm{~Hz}, 2 \mathrm{H}\right.$, benzene-H). ${ }^{13} \mathrm{C} \mathrm{NMR}\left(126 \mathrm{MHz}, \mathrm{CDCl}_{3}, 298 \mathrm{~K}\right) \delta(\mathrm{ppm}):-0.08,15.66$, $52.35,80.82,94.60,104.18,126.09,126.57,127.15,127.57,128.12,137.74,140.19,143.05$. HRMS (ASAP+, m/z): [M+H] ${ }^{+}$calcd. for $\mathrm{C}_{20} \mathrm{H}_{25} \mathrm{OSSi}$, 341.1395; found, 341.1403. 


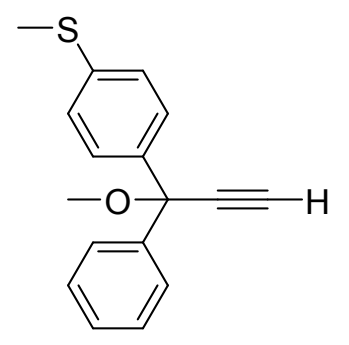

Synthesis of (4-(1-methoxy-1-phenylprop-2-yn-1-yl)phenyl)(methyl)sulfane (6). To the solution of compound $5(1.05 \mathrm{~g}, 3.08 \mathrm{mmol})$ in methanol $(75.0 \mathrm{~mL})$ was added $\mathrm{K}_{2} \mathrm{CO}_{3}(0.638 \mathrm{~g}$, $4.62 \mathrm{mmol})$. The reaction mixture was stirred for $3 \mathrm{~h}$ at room temperature, and subsequently quenched by the addition of saturated $\mathrm{NH}_{4} \mathrm{Cl}$ aqueous solution $(100.0 \mathrm{~mL})$, extracted with dichloromethane $(40.0 \mathrm{~mL} \times 3)$, combined organic layers were washed with saturated $\mathrm{NaCl}$ solution (40.0 mL), and dried over anhydrous $\mathrm{Na}_{2} \mathrm{SO}_{4}$, filtered, and concentrated to yield the compound 6 (0.818 g, 99\%) as a pink liquid. ${ }^{1} \mathrm{H} \mathrm{NMR}\left(400 \mathrm{MHz}, \mathrm{CDCl}_{3}, 298 \mathrm{~K}\right) \delta(\mathrm{ppm}): 2.46\left(\mathrm{~s}, 3 \mathrm{H},-\mathrm{SCH}_{3}\right)$, $2.88(\mathrm{~s}, 1 \mathrm{H},-\mathrm{C} \equiv \mathrm{CH}), 3.34\left(\mathrm{~s}, 3 \mathrm{H},-\mathrm{OCH}_{3}\right), 7.20(\mathrm{~d}, J 8.0 \mathrm{~Hz}, 2 \mathrm{H}$, benzene-H), 7.26-7.28 (m, 1H, benzene-H), 7.32 (t, J 8.0 Hz, 2H, benzene-H), 7.46 (d, J 8.0 Hz, 2H, benzene-H), 7.52-7.55 (m, 2H, benzene-H). ${ }^{13} \mathrm{C} \mathrm{NMR}\left(126 \mathrm{MHz}, \mathrm{CDCl}_{3}, 298 \mathrm{~K}\right) \delta(\mathrm{ppm}): 15.64,52.43,77.61,80.38,82.86$, $126.11,126.58,127.17,127.76,128.18,138.05,139.81,142.75 . \operatorname{HRMS}(\mathrm{ASAP}+, \mathrm{m} / \mathrm{z}):[\mathrm{M}+\mathrm{H}]^{+}$ calcd. for $\mathrm{C}_{17} \mathrm{H}_{17} \mathrm{OS}, 269.1000$; found, 269.0999 .

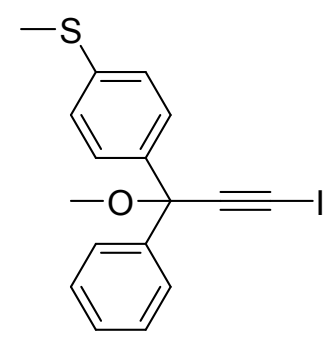

Synthesis of (4-(3-iodo-1-methoxy-1-phenylprop-2-yn-1-yl)phenyl)(methyl)sulfane (7). Under nitrogen atmosphere, $n$-butyl lithium $(1.37 \mathrm{~mL}, 3.43 \mathrm{mmol}, 2.5 \mathrm{M}$ in hexane) was added dropwise to the solution of compound $6(0.838 \mathrm{~g}, 3.12 \mathrm{mmol})$ in anhydrous THF $(50.0 \mathrm{~mL})$ over a $5 \mathrm{~min}$ period at $-78{ }^{\circ} \mathrm{C}$, with stirring. The mixture was stirred for $1.5 \mathrm{~h}$ at $-78{ }^{\circ} \mathrm{C}$. Then the reaction 
mixture was quenched with the solution of iodine $(0.949 \mathrm{~g}, 3.74 \mathrm{mmol})$ in anhydrous THF $(5.0$ $\mathrm{mL}$ ). The cooling bath was removed and the solution was stirred for $12 \mathrm{~h}$ at room temperature. Then the solution was poured into saturated $\mathrm{NH}_{4} \mathrm{Cl}$ aqueous solution $(100.0 \mathrm{~mL})$, extracted with ethyl acetate $(40.0 \mathrm{~mL} \times 3)$, combined organic layers were washed with saturated $\mathrm{Na}_{2} \mathrm{~S}_{2} \mathrm{O}_{3}$ aqueous solution $(50.0 \mathrm{~mL})$ and saturated $\mathrm{NaCl}$ solution $(50.0 \mathrm{~mL})$, and dried over anhydrous $\mathrm{Na}_{2} \mathrm{SO}_{4}$, filtered, and concentrated to yield the compound 7 (1.218 g, 99\%) as a yellow solid. ${ }^{1} \mathrm{H}$ NMR (400 $\left.\mathrm{MHz}, \mathrm{CDCl}_{3}, 298 \mathrm{~K}\right) \delta(\mathrm{ppm}): 2.46\left(\mathrm{~s}, 3 \mathrm{H},-\mathrm{SCH}_{3}\right), 3.33\left(\mathrm{~s}, 3 \mathrm{H},-\mathrm{OCH}_{3}\right), 7.19(\mathrm{~d}, J 8.0 \mathrm{~Hz}, 2 \mathrm{H}$, benzene-H), 7.26-7.34 (m, 3H, benzene-H), 7.41 (d, J 8.0 Hz, 2H, benzene-H), 7.49 (d, J 8.0 Hz, 2H, benzene-H). ${ }^{13} \mathrm{C}$ NMR (126 MHz, $\left.\mathrm{CDCl}_{3}, 298 \mathrm{~K}\right) \delta(\mathrm{ppm}): 6.11,15.65,52.66,81.96,94.05$, 126.13, 126.64, 127.20, 127.81, 128.20, 138.11, 139.87, 142.77. HRMS (ASAP+, m/z): [M] $]^{+}$calcd. for $\mathrm{C}_{17} \mathrm{H}_{15} \mathrm{OSI}$, 393.9888; found, 393.9883 .

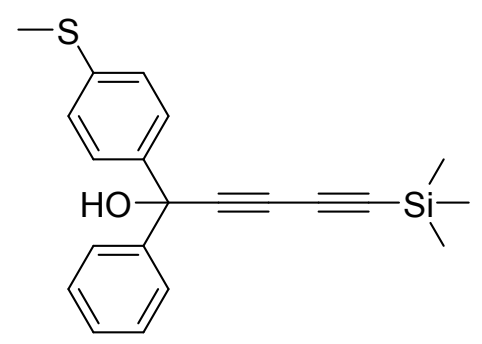

\section{Synthesis of 1-(4-(methylthio)phenyl)-1-phenyl-5-(trimethylsilyl)penta-2,4-diyn-1-ol (8).}

Under nitrogen atmosphere, methyllithium lithium bromide complex solution $(1.54 \mathrm{~mL}, 2.31$ $\mathrm{mmol}, 1.5 \mathrm{M}_{\text {in }} \mathrm{Et}_{2} \mathrm{O}$ ) was added dropwise to the solution of 1,4-bis(trimethylsilyl)-1,3-butadiyne $(0.428 \mathrm{~g}, 2.2 \mathrm{mmol})$ in anhydrous $\mathrm{THF}(6.0 \mathrm{~mL})$ over a $5 \min$ period at $0{ }^{\circ} \mathrm{C}$, with stirring. The resulting solution was warmed to room temperature and stirred for $45 \mathrm{~min}$. Then the solution of compound $1(0.502 \mathrm{~g}, 2.2 \mathrm{mmol})$ in anhydrous THF $(3.0 \mathrm{~mL})$ was added over a $5 \mathrm{~min}$ period at $0{ }^{\circ} \mathrm{C}$. The solution was stirred for $12 \mathrm{~h}$ at room temperature. Then the solution was poured into saturated $\mathrm{NH}_{4} \mathrm{Cl}$ aqueous solution $(20.0 \mathrm{~mL})$, extracted with diethyl ether $(20.0 \mathrm{~mL} \times 3)$, combined 
organic layers were washed with saturated $\mathrm{NaCl}$ solution $(20.0 \mathrm{~mL})$, and dried over anhydrous $\mathrm{Na}_{2} \mathrm{SO}_{4}$, filtered, and concentrated. The residue was purified by column chromatography ( $24 \mathrm{~g}$ Redisep $\mathrm{R}_{\mathrm{f}}$ Silica) using a gradient from $0 \%$ to $20 \%$ ethyl acetate/hexanes to give the compound $\mathbf{8}$ $(0.402 \mathrm{~g}, 52 \%)$ as a light-pink liquid. ${ }^{1} \mathrm{H}$ NMR $\left(400 \mathrm{MHz}, \mathrm{CDCl}_{3}, 298 \mathrm{~K}\right) \delta(\mathrm{ppm}): 0.21$ (s, 9H, $\left.\mathrm{Si}\left(\mathrm{CH}_{3}\right)_{3}\right), 2.46$ (s, 3H, $\left.-\mathrm{SCH}_{3}\right), 2.72(\mathrm{~s}, 1 \mathrm{H},-\mathrm{OH}), 7.21(\mathrm{~d}, J 12.0 \mathrm{~Hz}, 2 \mathrm{H}$, benzene-H), 7.28-7.35 (m, 3H, benzene-H), $7.46\left(\mathrm{~d}, J 12.0 \mathrm{~Hz}, 2 \mathrm{H}\right.$, benzene-H), 7.52-7.55 (m, 2H, benzene-H). ${ }^{13} \mathrm{C}$ NMR $\left(126 \mathrm{MHz}, \mathrm{CDCl}_{3}, 298 \mathrm{~K}\right) \delta(\mathrm{ppm}):-0.51,15.63,72.18,74.57,79.03,87.03,89.47,126.01,126.21$, 126.56, 128.09, 128.39, 138.57, 140.78, 143.78. HRMS $(A S A P+, m / z):[M]^{+}$calcd. for $\mathrm{C}_{21} \mathrm{H}_{22} \mathrm{OSSi}$, 350.1161; found, 350.1153 .

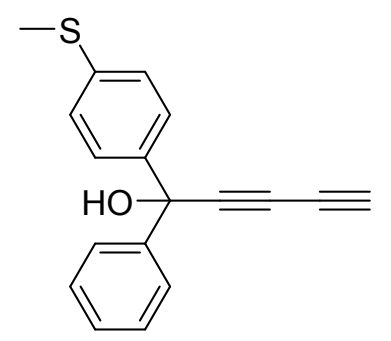

Synthesis of 1-(4-(methylthio)phenyl)-1-phenylpenta-2,4-diyn-1-ol (9). To the solution of compound $8(0.40 \mathrm{~g}, 1.14 \mathrm{mmol})$ in methanol $(25.0 \mathrm{~mL})$ was added $\mathrm{K}_{2} \mathrm{CO}_{3}(0.236 \mathrm{~g}, 1.71 \mathrm{mmol})$. The reaction mixture was stirred for $3 \mathrm{~h}$ at room temperature, and subsequently quenched by the addition of saturated $\mathrm{NH}_{4} \mathrm{Cl}$ aqueous solution $(50.0 \mathrm{~mL})$, extracted with dichloromethane (20.0 $\mathrm{mL} \times 3)$, combined organic layers were washed with saturated $\mathrm{NaCl}$ solution $(20.0 \mathrm{~mL})$, and dried over anhydrous $\mathrm{Na}_{2} \mathrm{SO}_{4}$, filtered, and concentrated to yield the compound $9(0.310 \mathrm{~g}, 98 \%)$ as a purple liquid. ${ }^{1} \mathrm{H}$ NMR (500 MHz, $\left.\mathrm{CDCl}_{3}, 298 \mathrm{~K}\right) \delta(\mathrm{ppm}): 2.32(\mathrm{~s}, 1 \mathrm{H},-\mathrm{C} \equiv \mathrm{CH}), 2.47$ (s, 3H, $\left.\mathrm{SCH}_{3}\right), 2.80$ (s, 1H, -OH), 7.21 (d, $J 10.0 \mathrm{~Hz}, 2 \mathrm{H}$, benzene-H), 7.30 (t, $J 7.5 \mathrm{~Hz}, 1 \mathrm{H}$, benzene-H), 7.35 (t, $J 7.5 \mathrm{~Hz}, 2 \mathrm{H}$, benzene-H), $7.46(\mathrm{~d}, J 10.0 \mathrm{~Hz}, 2 \mathrm{H}$, benzene-H), 7.53-7.55 (m, 2H, benzeneH). ${ }^{13} \mathrm{C} \mathrm{NMR}\left(101 \mathrm{MHz}, \mathrm{CDCl}_{3}, 298 \mathrm{~K}\right) \delta(\mathrm{ppm}): 15.61,67.32,70.06,71.41,74.48,77.86,125.96$, 
126.25, 126.52, 128.17, 128.44, 138.71, 140.59, 143.62. HRMS (ASAP+, m/z): [M] $]^{+}$calcd. for $\mathrm{C}_{18} \mathrm{H}_{14} \mathrm{OS}, 278.0765$; found, 278.0767 .

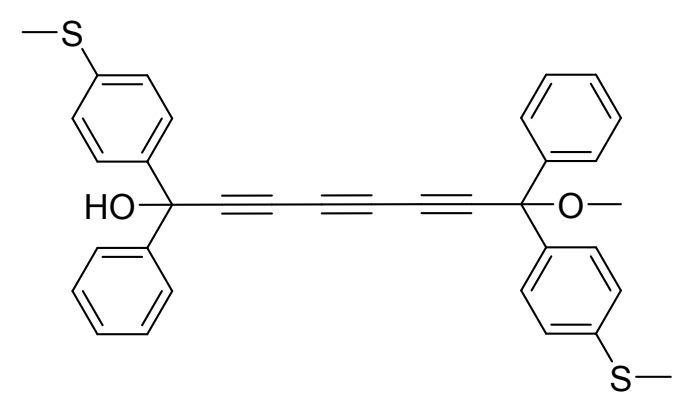

Synthesis of 8-methoxy-1,8-bis(4-(methylthio)phenyl)-1,8-diphenylocta-2,4,6-triyn-1-ol (10).

To the solution of compound $9(0.298 \mathrm{~g}, 1.07 \mathrm{mmol})$ and compound $7(0.568 \mathrm{~g}, 1.44 \mathrm{mmol})$ in degassed ethanol $(80.0 \mathrm{~mL})$ were added $\mathrm{CuCl}(0.178 \mathrm{~g}, 1.80 \mathrm{mmol})$ and $\mathrm{NH}_{2} \mathrm{OH} \cdot \mathrm{HCl}(0.149 \mathrm{~g}$, $2.14 \mathrm{mmol}$ ) at room temperature, and the mixture was purged with nitrogen for $15 \mathrm{~min}$. Then $n$ $\mathrm{PrNH}_{2}(0.38 \mathrm{~mL}, 4.60 \mathrm{mmol})$ was added dropwise using a syringe. The mixture was purged with nitrogen for further $10 \mathrm{~min}$ and stirred for $19 \mathrm{~h}$ at room temperature. The reaction was quenched by addition of $\mathrm{H}_{2} \mathrm{O}(150.0 \mathrm{~mL})$, extracted with dichloromethane $(30.0 \mathrm{~mL} \times 3)$, combined organic layers were washed with saturated $\mathrm{NH}_{4} \mathrm{Cl}$ solution $(30.0 \mathrm{~mL} \times 2)$ and saturated $\mathrm{NaCl}$ solution $(30.0$ $\mathrm{mL}$ ), and dried over anhydrous $\mathrm{Na}_{2} \mathrm{SO}_{4}$, filtered, and concentrated. The residue was purified by column chromatography ( $24 \mathrm{~g}$ Redisep $\mathrm{R}_{\mathrm{f}}$ Silica) using a gradient from $0 \%$ to $20 \%$ ethyl acetate/hexanes to give the compound $10(0.292 \mathrm{~g}, 50 \%)$ as an off-white solid. ${ }^{1} \mathrm{H}$ NMR (500 MHz, $\left.\mathrm{CDCl}_{3}, 298 \mathrm{~K}\right) \delta(\mathrm{ppm}): 2.46\left(\mathrm{~s}, 3 \mathrm{H},-\mathrm{SCH}_{3}\right), 2.47\left(\mathrm{~s}, 3 \mathrm{H},-\mathrm{SCH}_{3}\right), 2.80(\mathrm{~s}, 1 \mathrm{H},-\mathrm{OH}), 3.32(\mathrm{~s}, 3 \mathrm{H}$, $\left.-\mathrm{OCH}_{3}\right), 7.20$ (t, $J 10.0 \mathrm{~Hz}, 4 \mathrm{H}$, benzene-H), 7.28-7.38 (m, 8H, benzene-H), 7.43-7.47 (m, 4H, benzene-H), 7.51-7.54 (m, 2H, benzene-H). ${ }^{13} \mathrm{C}$ NMR (101 MHz, $\left.\mathrm{CDCl}_{3}, 298 \mathrm{~K}\right) \delta(\mathrm{ppm}): 15.58$, $15.60,52.85,63.79,64.42,71.92,73.83,74.72,78.64,80.55,81.15,125.97,126.14,126.26$, $126.52,126.66,127.19,128.12,128.28,128.34,128.50,128.52,138.63,138.90,138.94,140.38$ 141.94, 143.45. HRMS (ASAP+, m/z): [M-OH] $]^{+}$calcd. for $\mathrm{C}_{35} \mathrm{H}_{27} \mathrm{OS}_{2}, 527.1498$; found, 527.1503. 


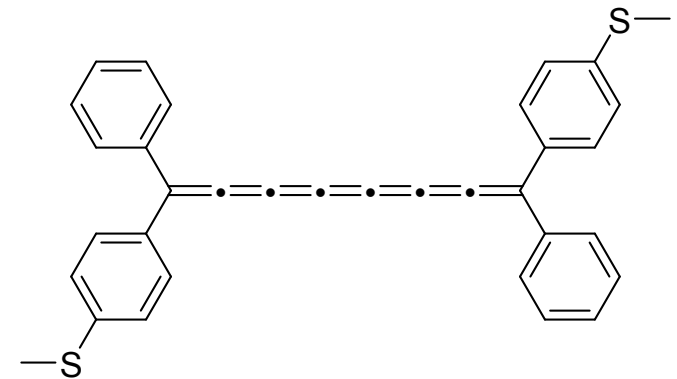

\section{Synthesis of 1,8-bis(4-(methylthio)phenyl)-1,8-diphenylocta-1,2,3,4,5,6,7-heptaene (C8).}

Under nitrogen atmosphere, hydrogen chloride solution $\left(0.12 \mathrm{~mL}, 0.12 \mathrm{mmol}, 1.0 \mathrm{M}\right.$ in $\left.\mathrm{Et}_{2} \mathrm{O}\right)$ was added dropwise to the mixture of compound $\mathbf{1 0}(0.022 \mathrm{~g}, 0.04 \mathrm{mmol})$ and anhydrous $\mathrm{SnCl}_{2}(0.023$ $\mathrm{g}, 0.12 \mathrm{mmol})$ in degassed dichloromethane $(3.2 \mathrm{~mL})$ and diethyl ether $(0.8 \mathrm{~mL})$ over a $5 \mathrm{~min}$ period at $-78^{\circ} \mathrm{C}$ and stirred for another $45 \mathrm{~min}$ at $-78^{\circ} \mathrm{C}$. Then the solution was filtered through a plug of basic alumina oxide and eluted with degassed dichloromethane $(20.0 \mathrm{~mL})$ to afford the purified compound $\mathbf{C 8}$ as a blue solution under nitrogen atmosphere. The yield could not be determined due to instability of this compound in solid state. The resulting solution was added to various degassed solvents, respectively, and concentrated in vacuum to give the corresponding samples that were tested immediately. ${ }^{1} \mathrm{H}$ NMR $\left(500 \mathrm{MHz}, \mathrm{C}_{2} \mathrm{D}_{2} \mathrm{Cl}_{4}, 298 \mathrm{~K}\right) \delta(\mathrm{ppm}): 2.54(\mathrm{~s}, 6 \mathrm{H}$, $\left.-\mathrm{SCH}_{3}\right), 7.26(\mathrm{~d}, J 5.0 \mathrm{~Hz}, 4 \mathrm{H}$, benzene-H), 7.38-7.45 (m, 6H, benzene-H), $7.52(\mathrm{~d}, J 10.0 \mathrm{~Hz}, 4 \mathrm{H}$, benzene-H), 7.58 (dd, $J 10.0 \mathrm{~Hz}, 4 \mathrm{H}$, benzene-H). ${ }^{13} \mathrm{C} \mathrm{NMR}\left(126 \mathrm{MHz}, \mathrm{C}_{2} \mathrm{D}_{2} \mathrm{Cl}_{4}, 298 \mathrm{~K}\right) \delta(\mathrm{ppm})$ : $15.39,124.18,124.92,125.92,128.87,129.26,129.62,129.84,134.27,137.44,140.57,144.27$, 145.89. HRMS (ESI+, m/z): [M] ${ }^{+}$calcd. for $\mathrm{C}_{34} \mathrm{H}_{24} \mathrm{~S}_{2}, 496.1319$; found, 496.1337. 


\section{NMR Spectra}

\section{${ }^{1} \mathrm{H}$ NMR spectrum of 1}

으를
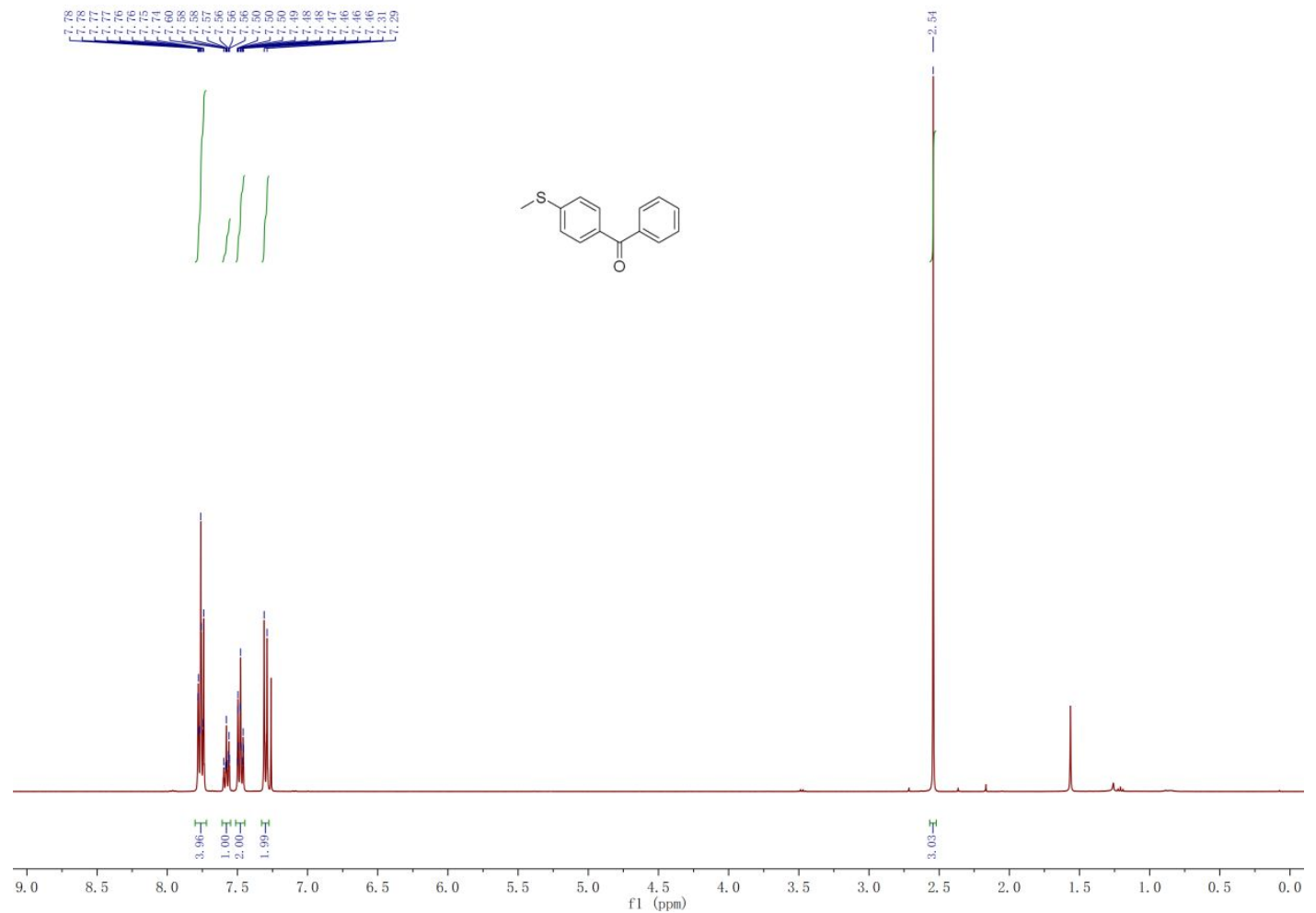

\section{${ }^{13}$ C NMR spectrum of 1}
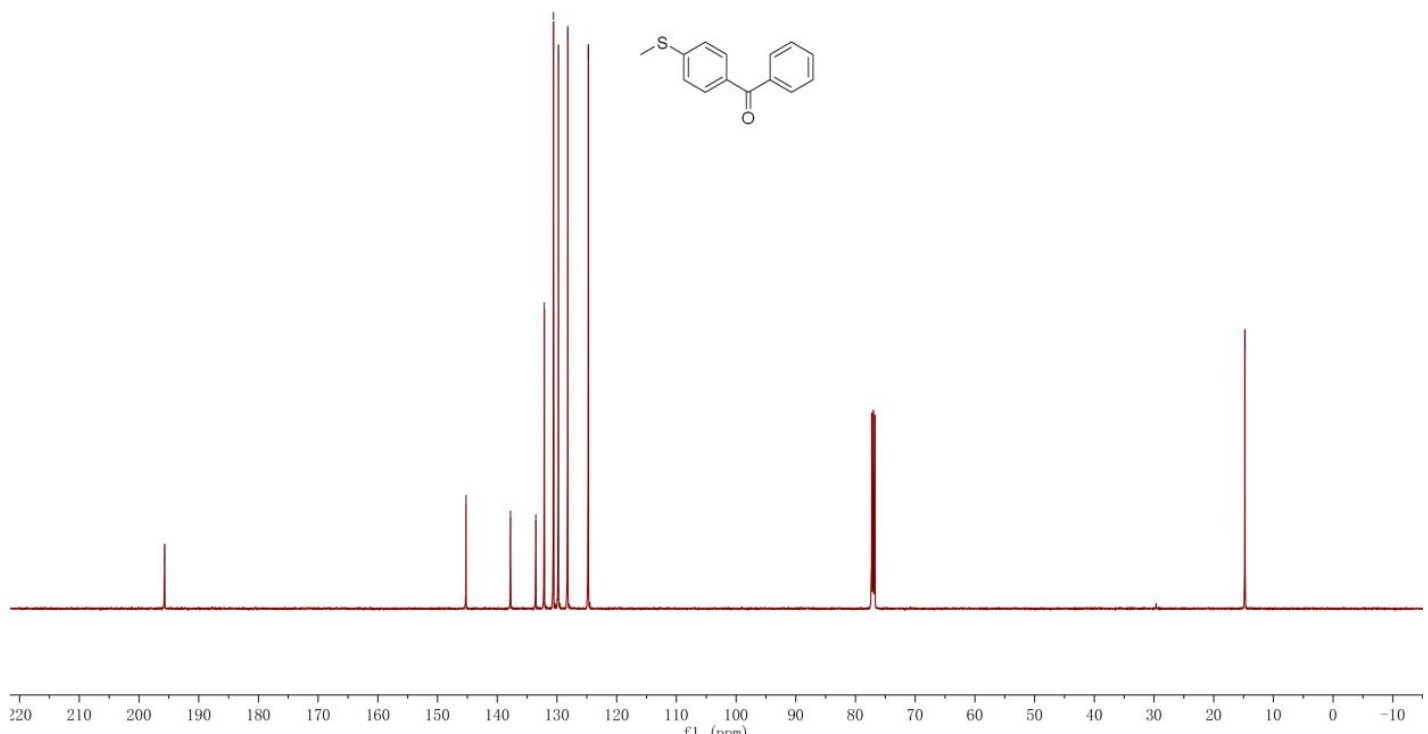


\section{${ }^{1}$ H NMR spectrum of 2}

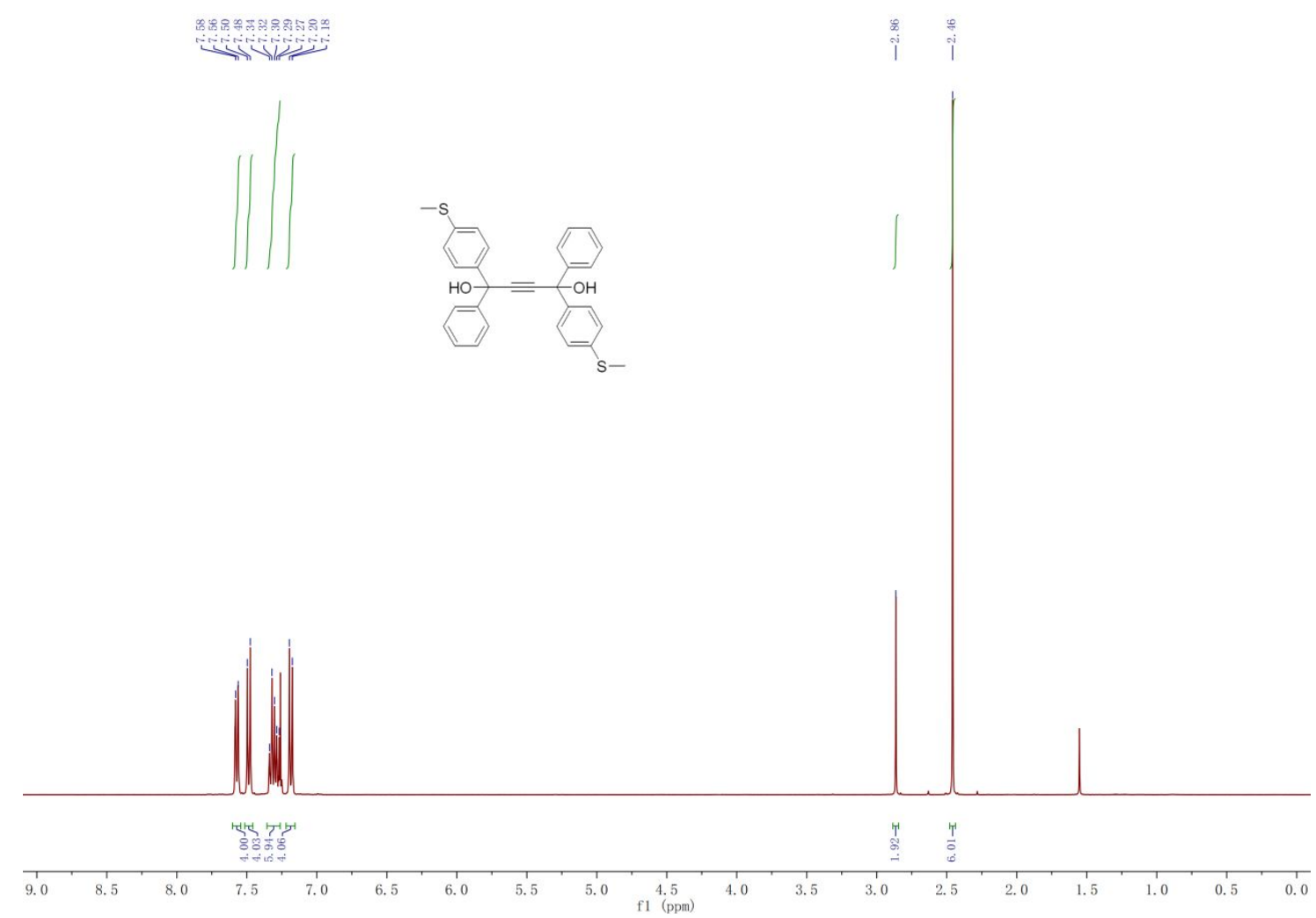

\section{${ }^{13}$ C NMR spectrum of 2}
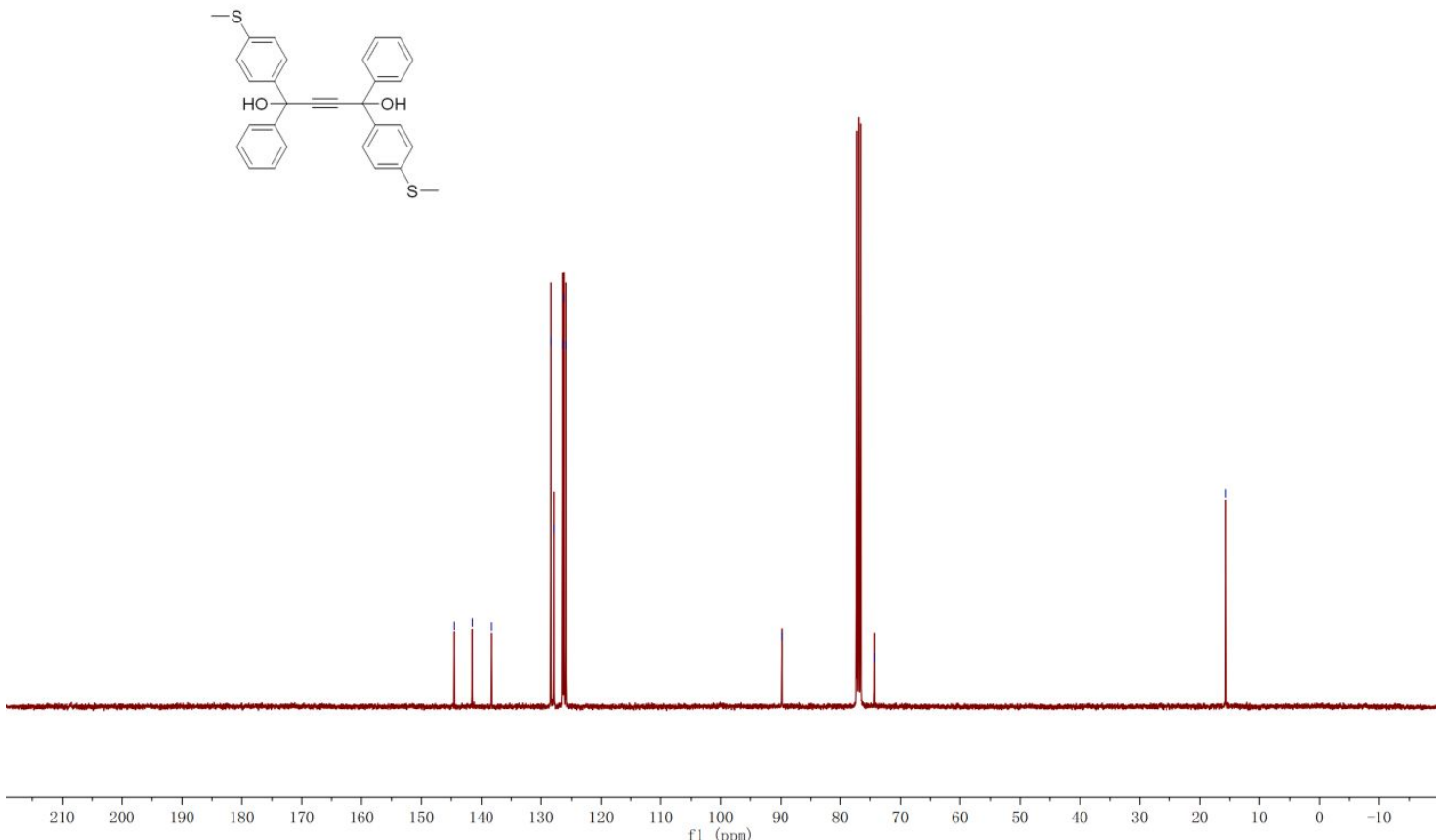


\section{${ }^{1} \mathrm{H}$ NMR spectrum of C4}

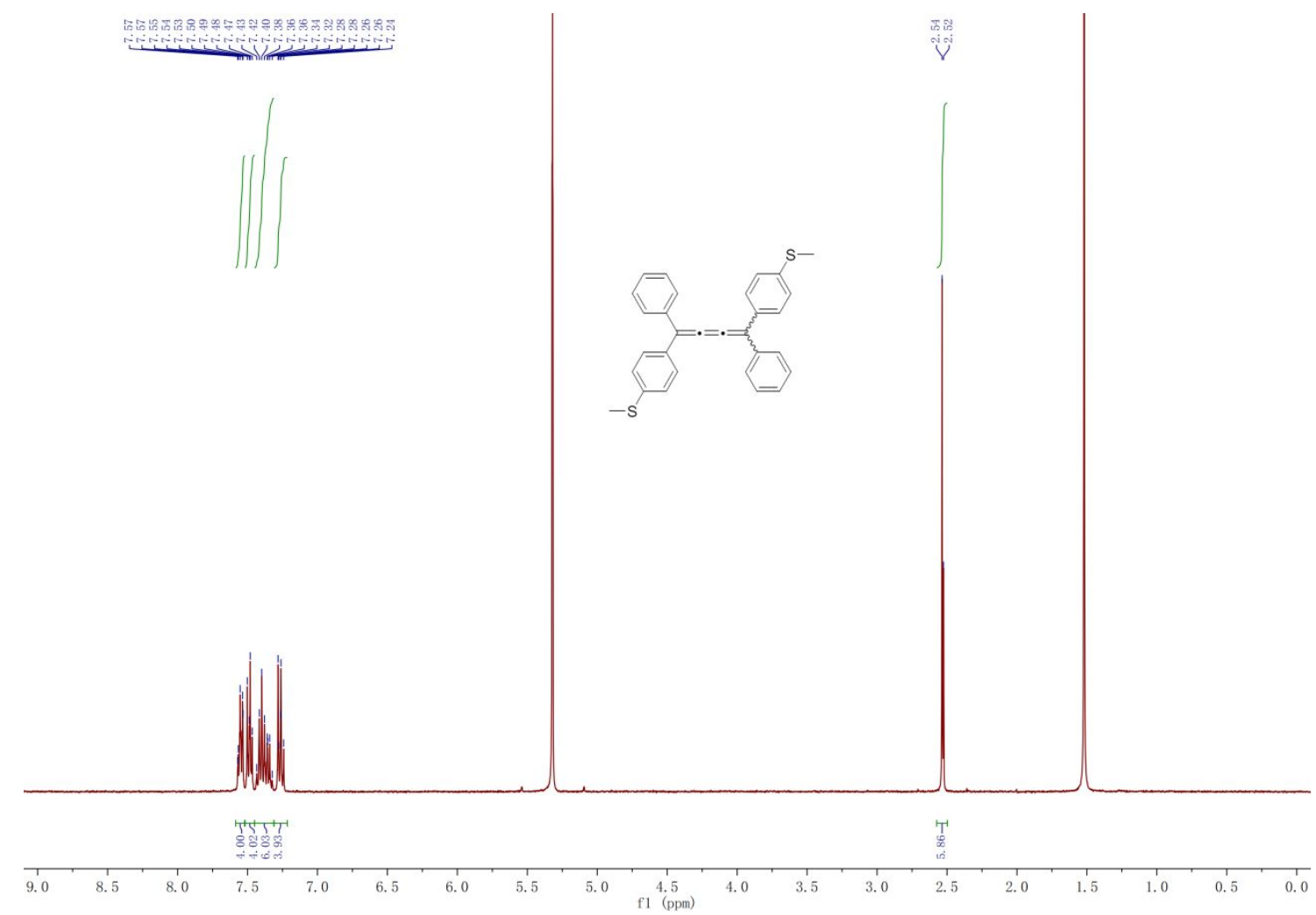

\section{${ }^{13} \mathrm{C} N M R$ spectrum of $C 4$}

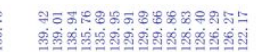

YYV
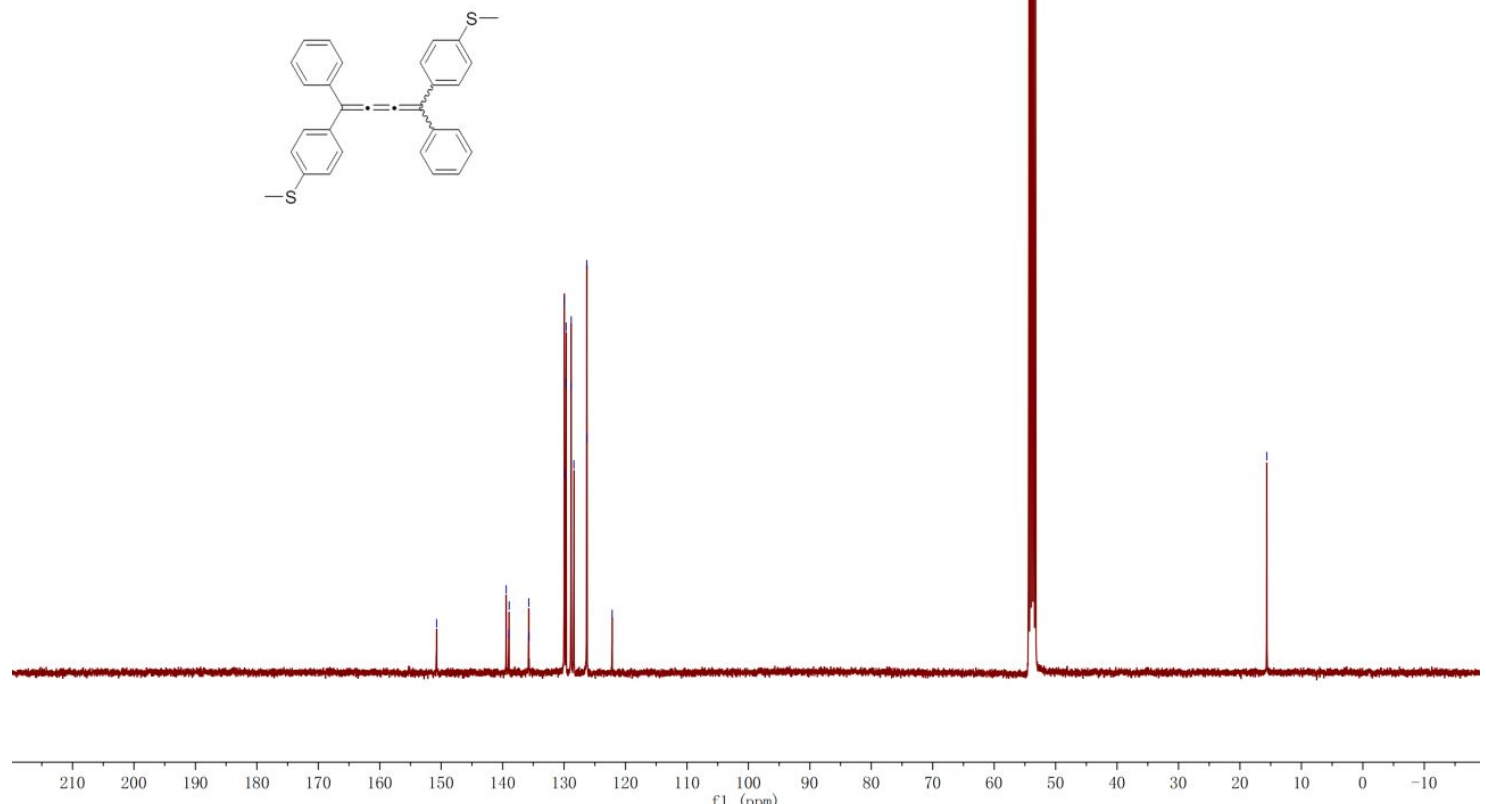


\section{${ }^{1} \mathrm{H}$ NMR spectrum of 3}

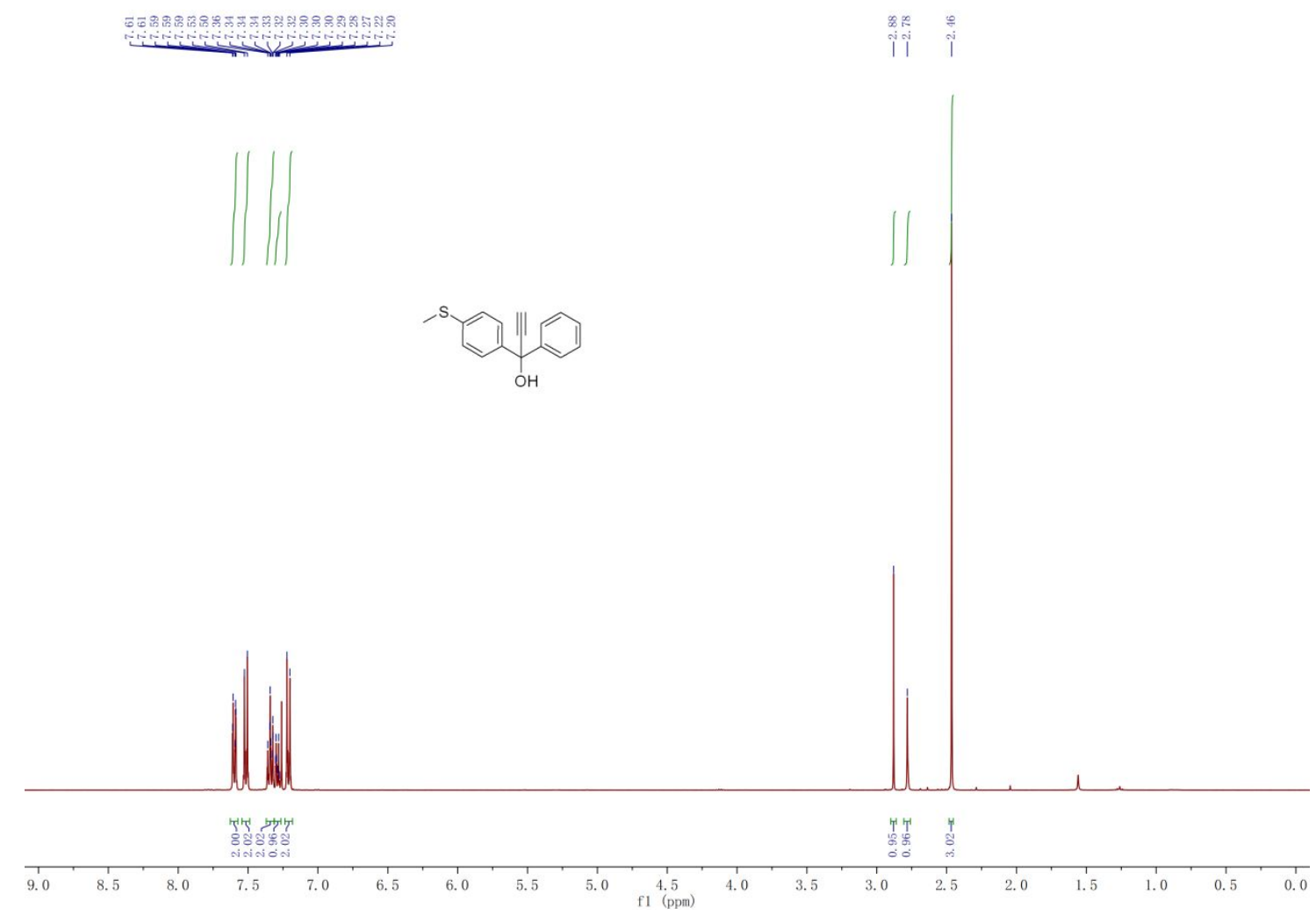

\section{${ }^{13}$ C NMR spectrum of 3}
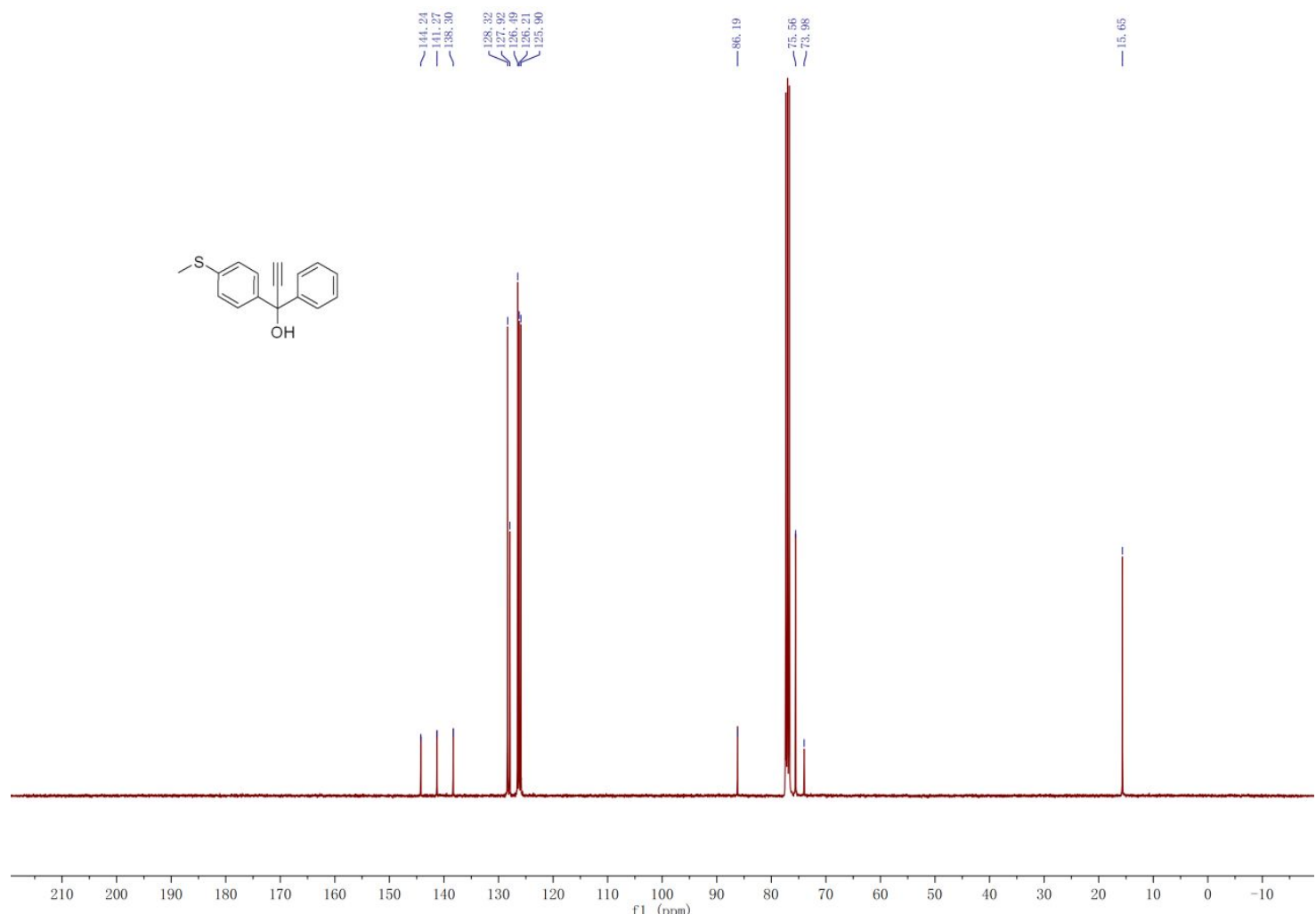
${ }^{1} \mathrm{H}$ NMR spectrum of 4
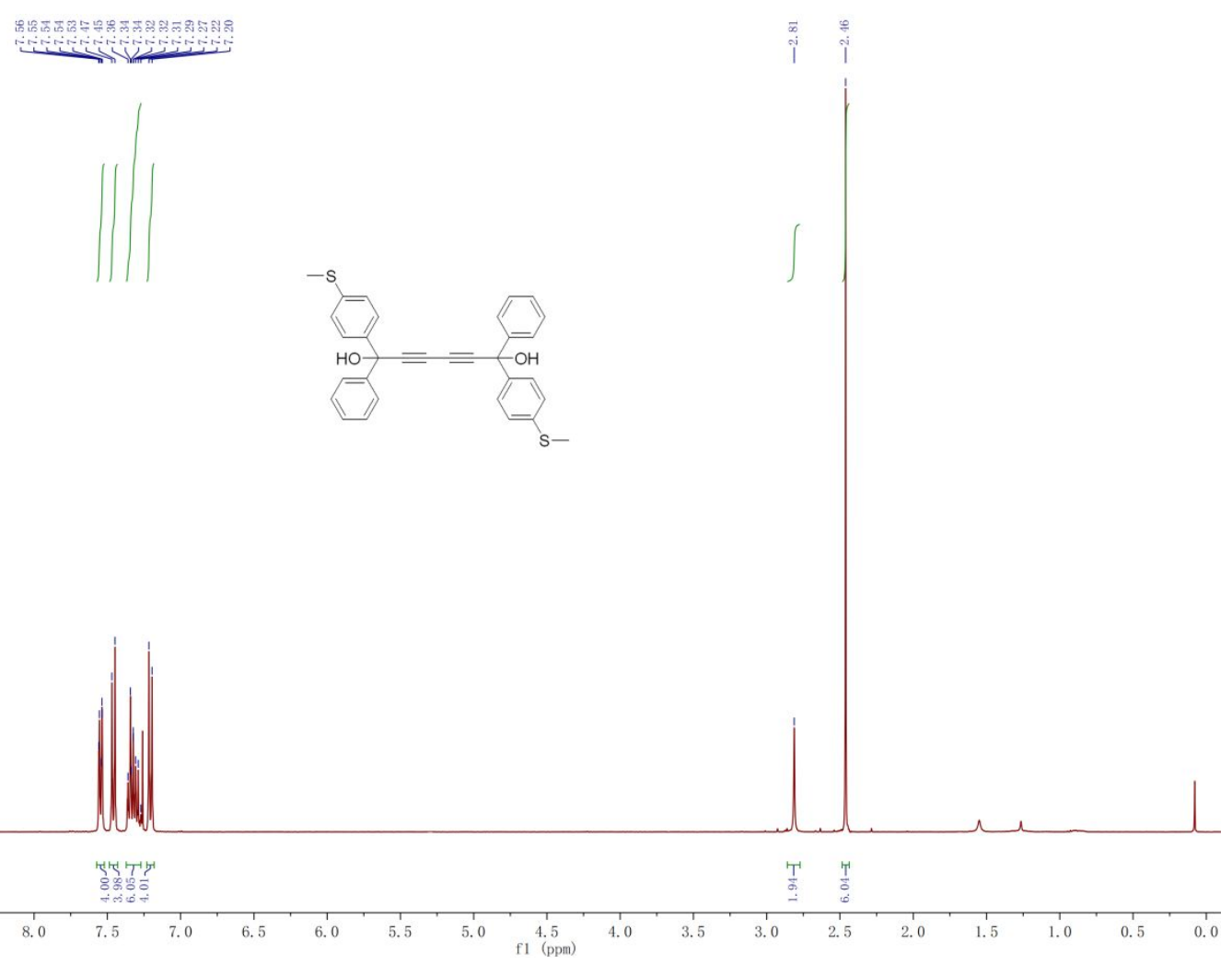

${ }^{13}$ C NMR spectrum of 4

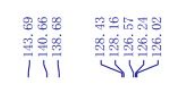

ข

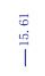
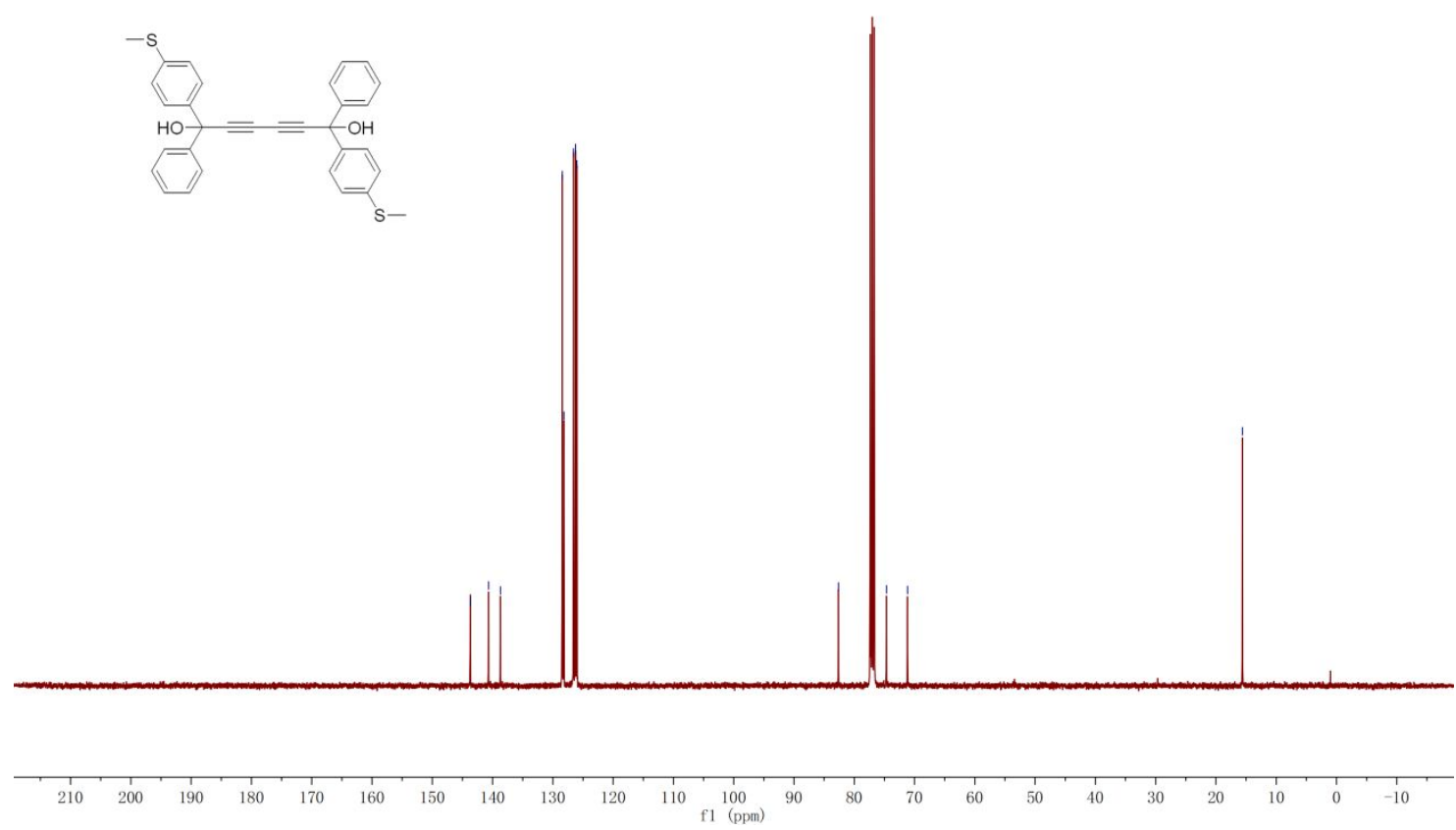


\section{${ }^{1} \mathrm{H}$ NMR spectrum of C6}

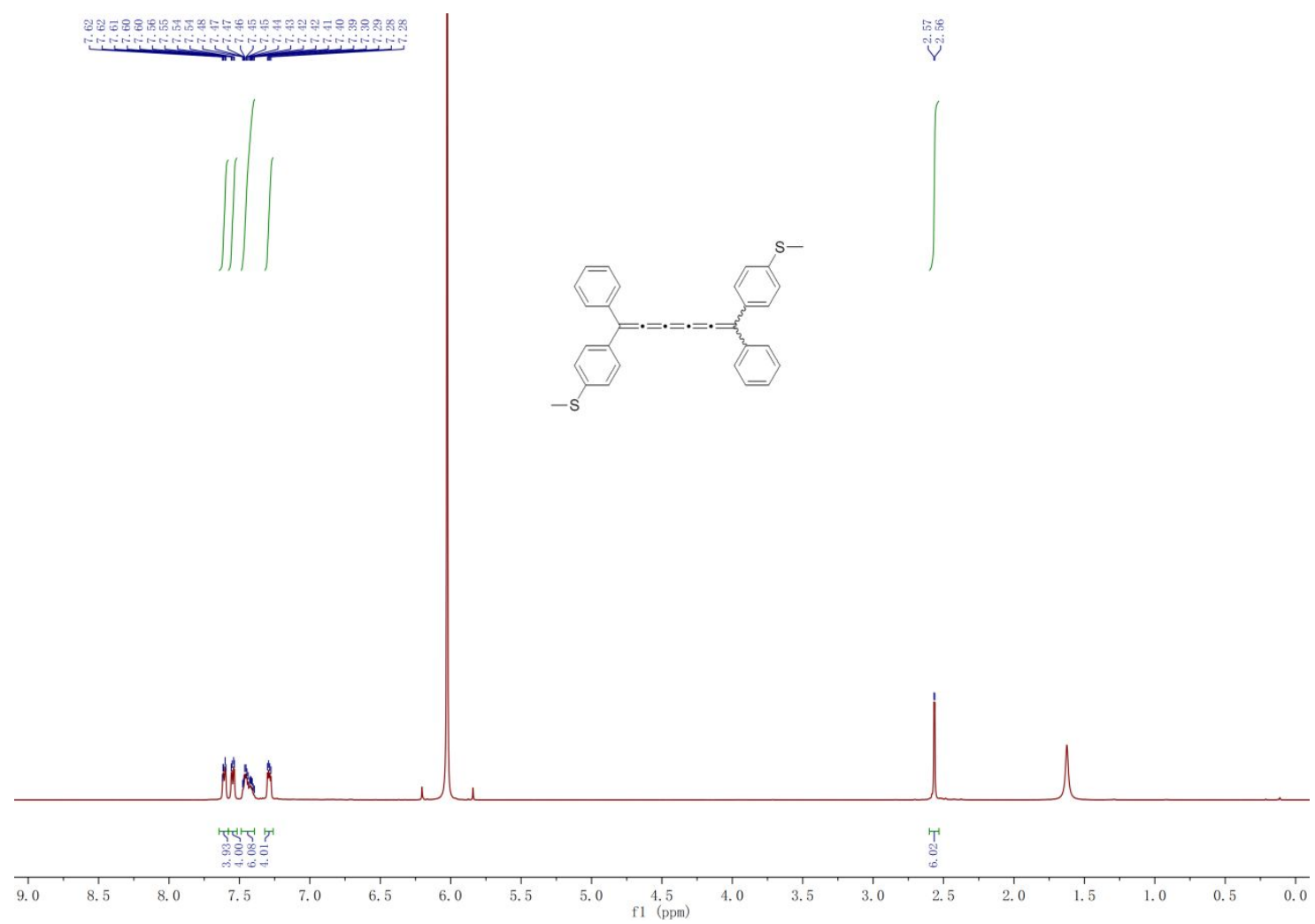

${ }^{13}$ C NMR spectrum of C6
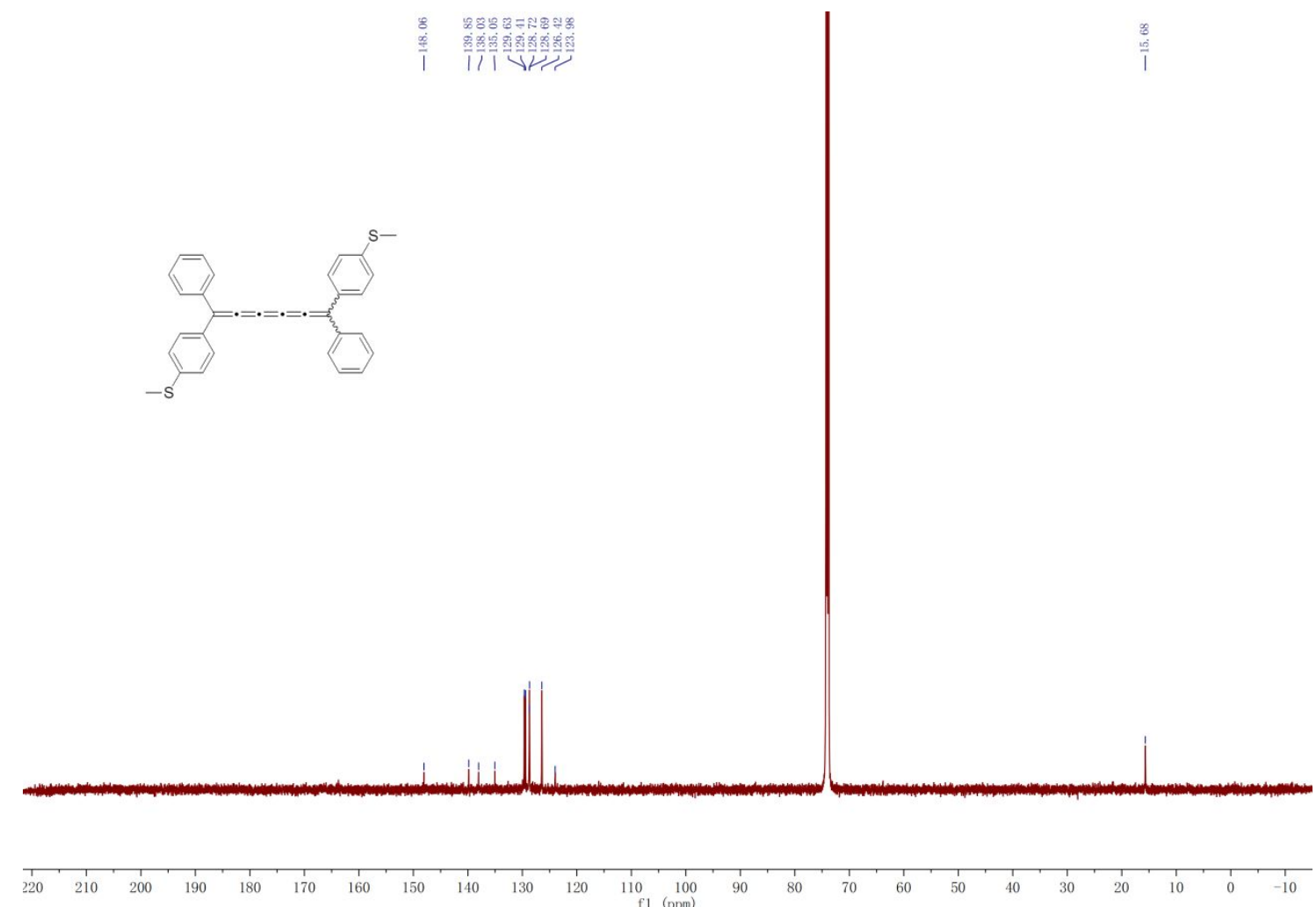
${ }^{1} \mathrm{H} N M R$ spectrum of 5

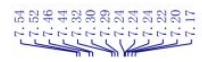

II I

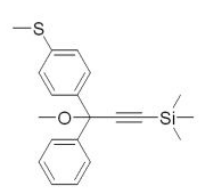

i
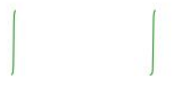

${ }^{13}$ C NMR spectrum of 5

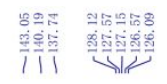

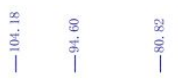

象
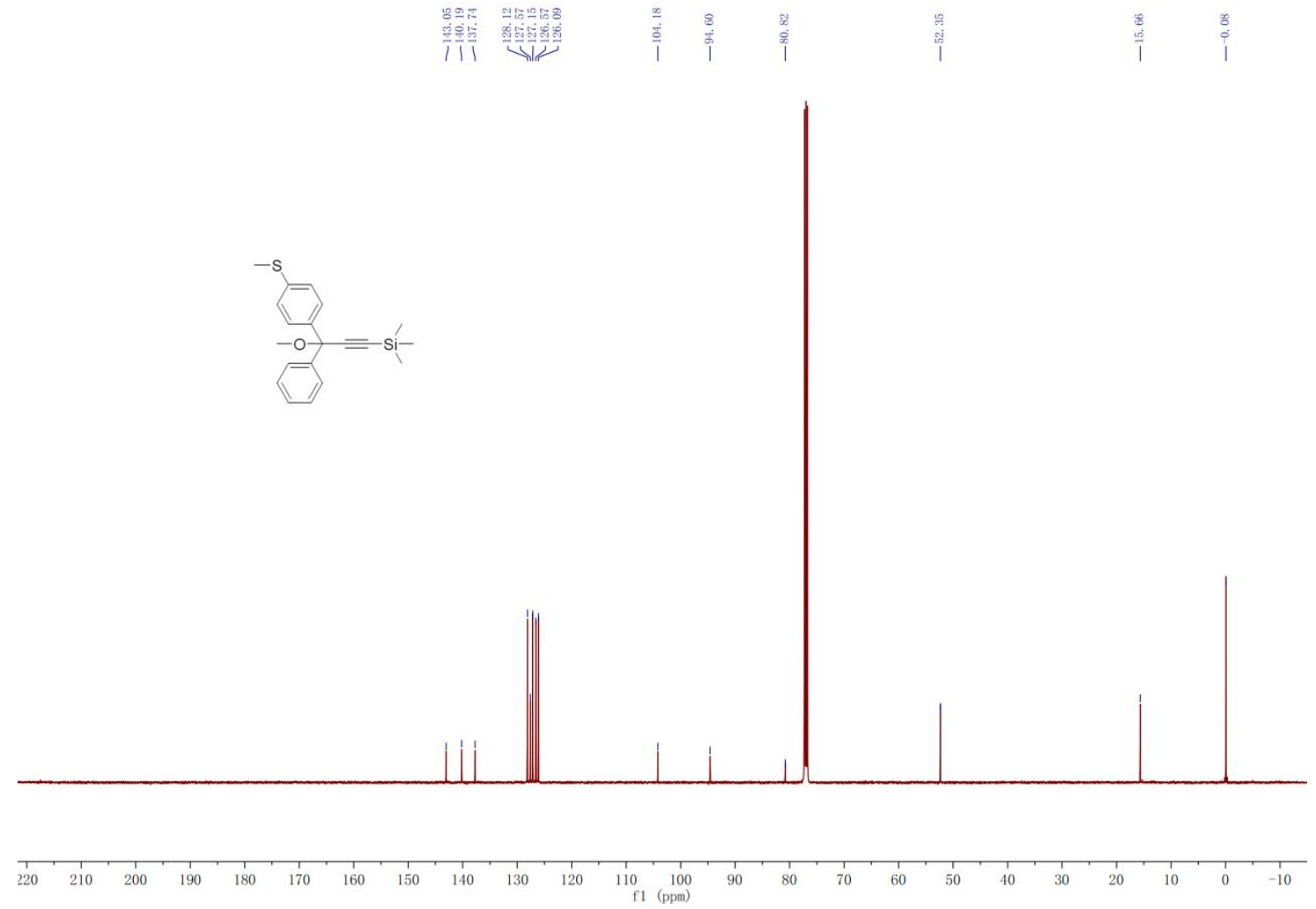
${ }^{1} \mathrm{H} N M R$ spectrum of 6
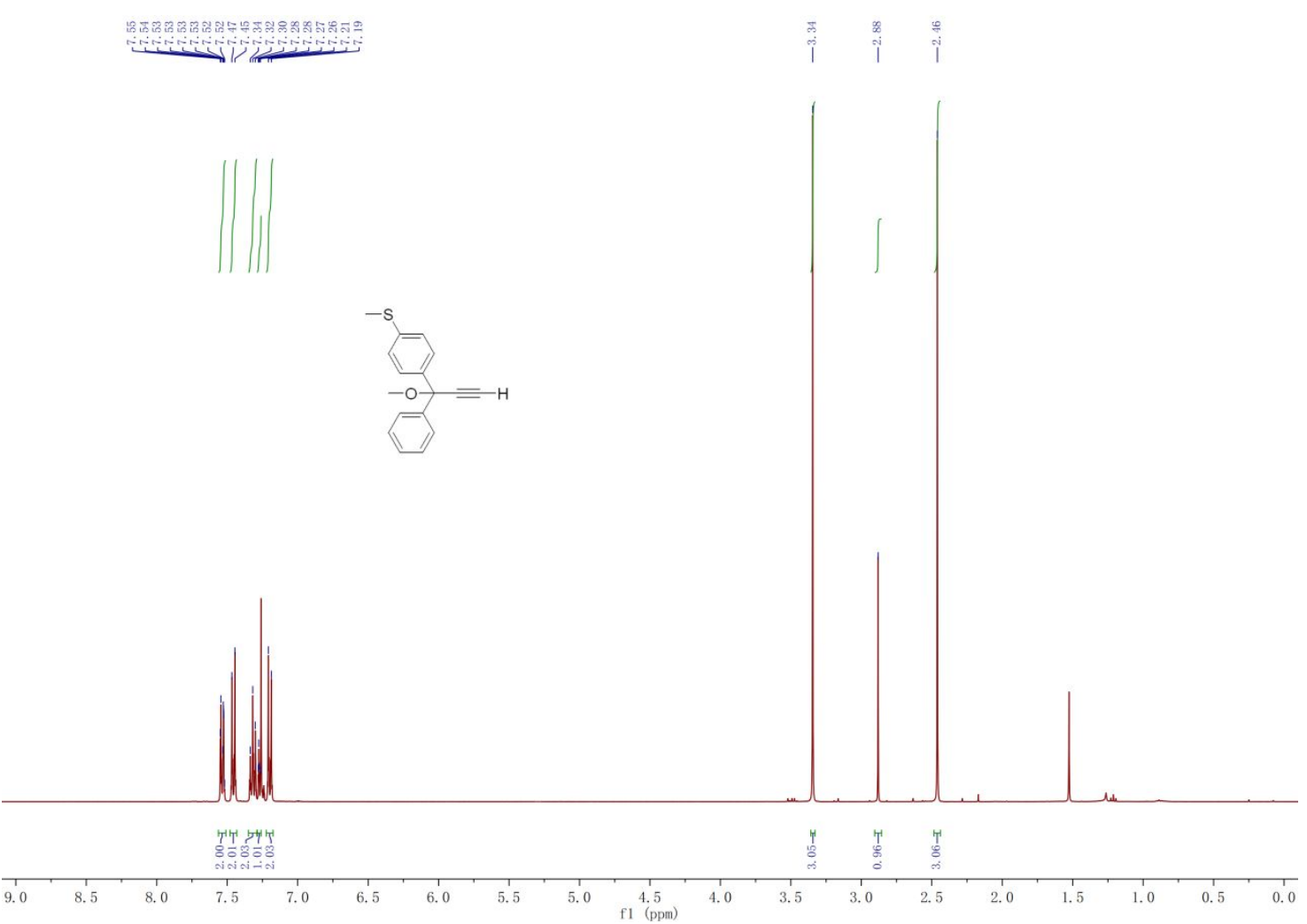

${ }^{13}$ C NMR spectrum of 6

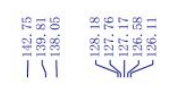
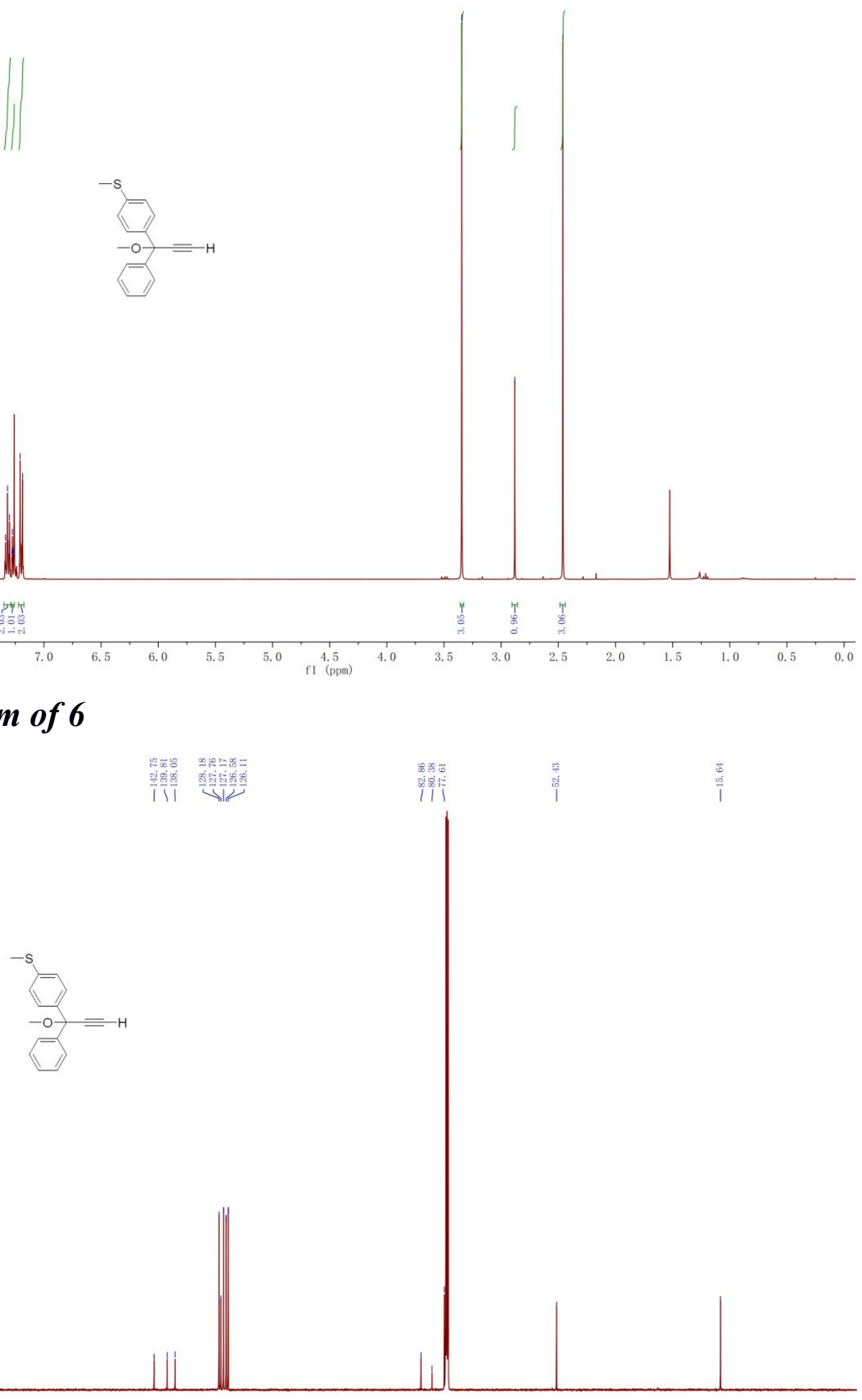
${ }^{1} \mathrm{H} N M R$ spectrum of 7
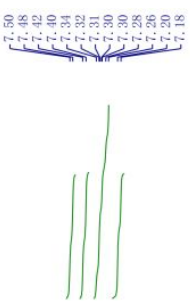

i

(

$-\mathrm{s}$

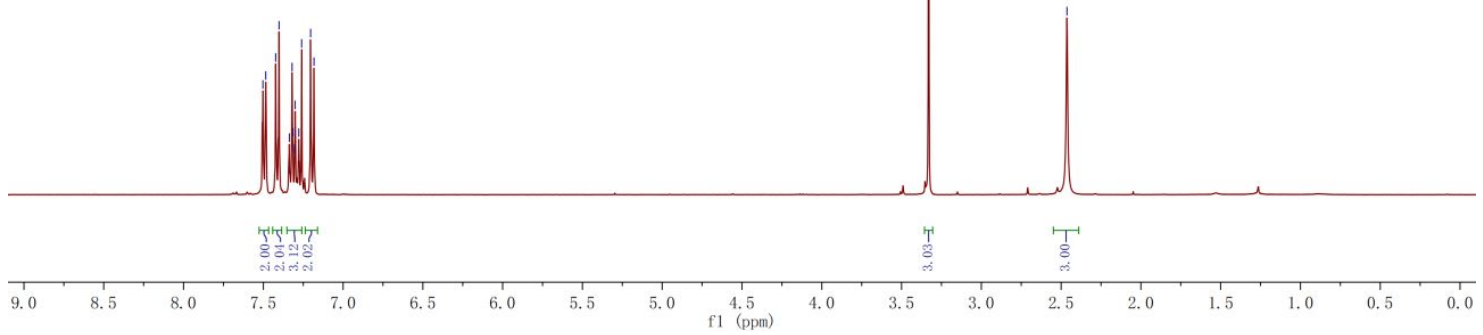

${ }^{13}$ C NMR spectrum of 7

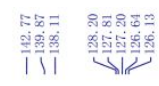

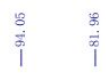

1

$\begin{array}{ll}18 \\ 1 & 0 \\ 1 & 0\end{array}$
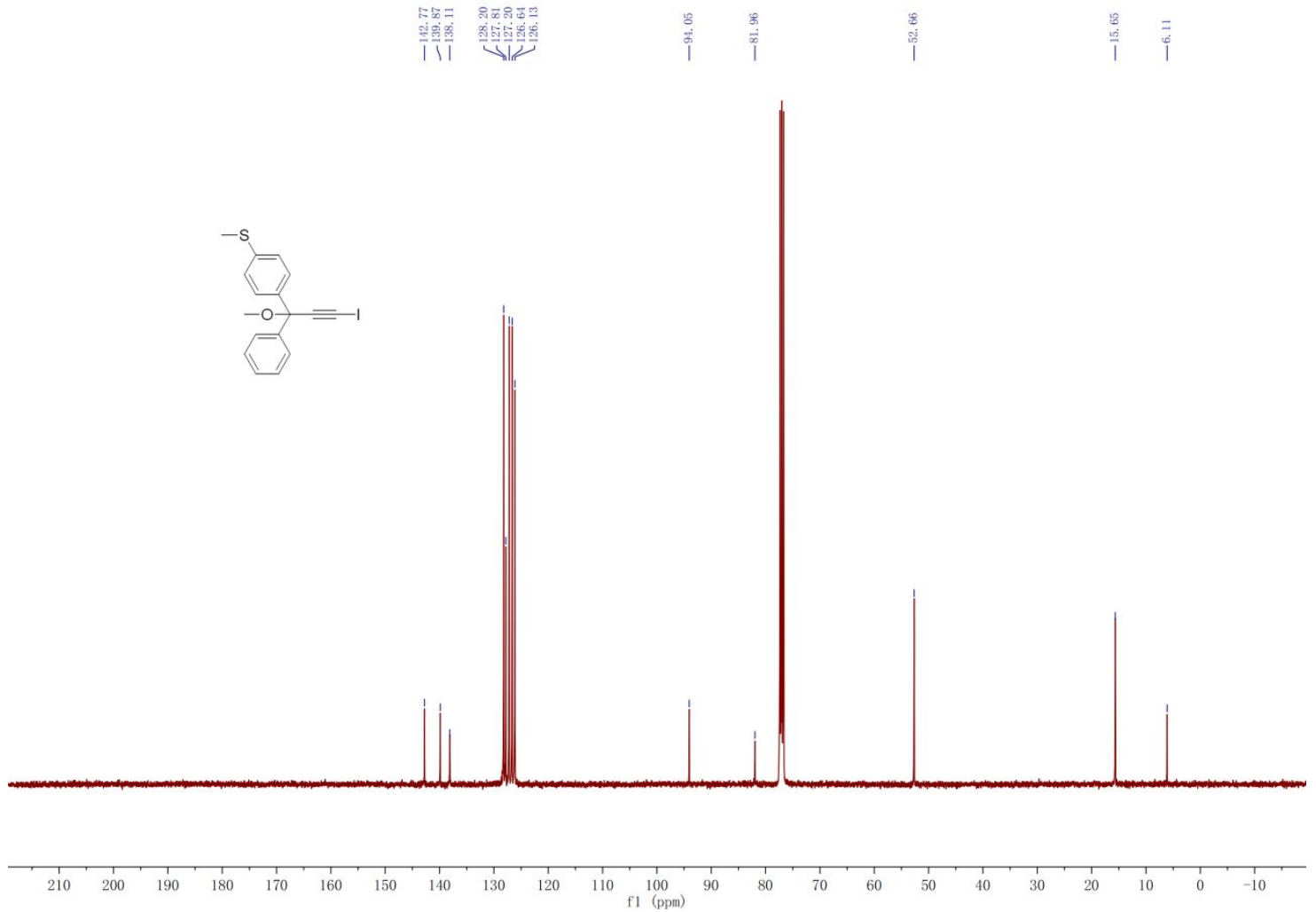
${ }^{1} \mathrm{H}$ NMR spectrum of 8

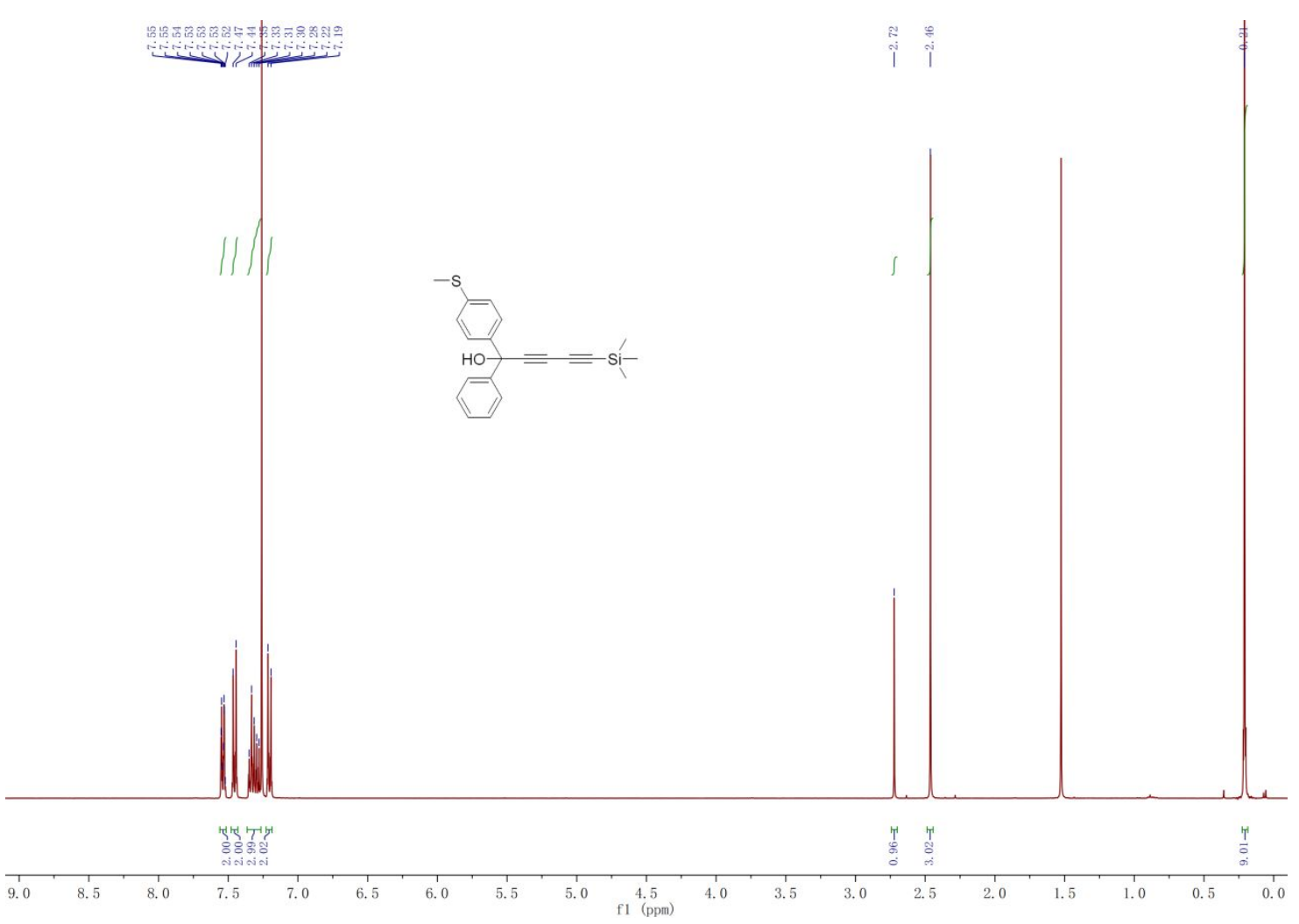

${ }^{13}$ C NMR spectrum of 8

筑
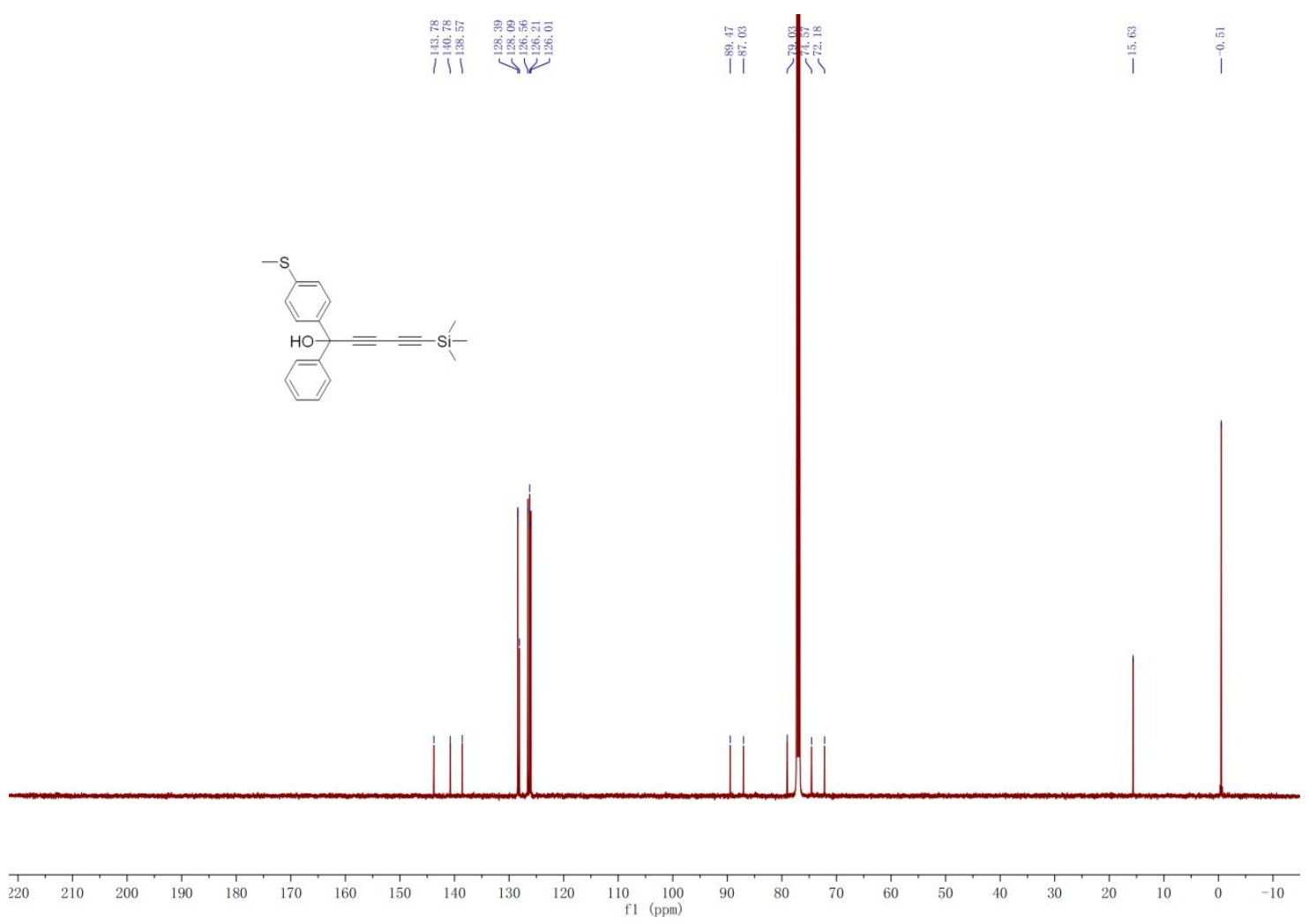


\section{${ }^{1}$ H NMR spectrum of 9}

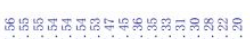

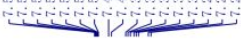

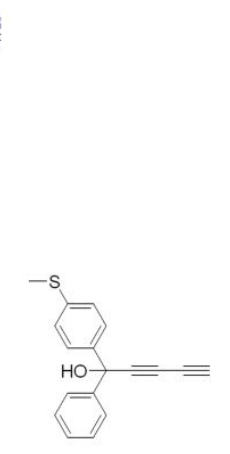

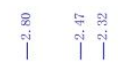
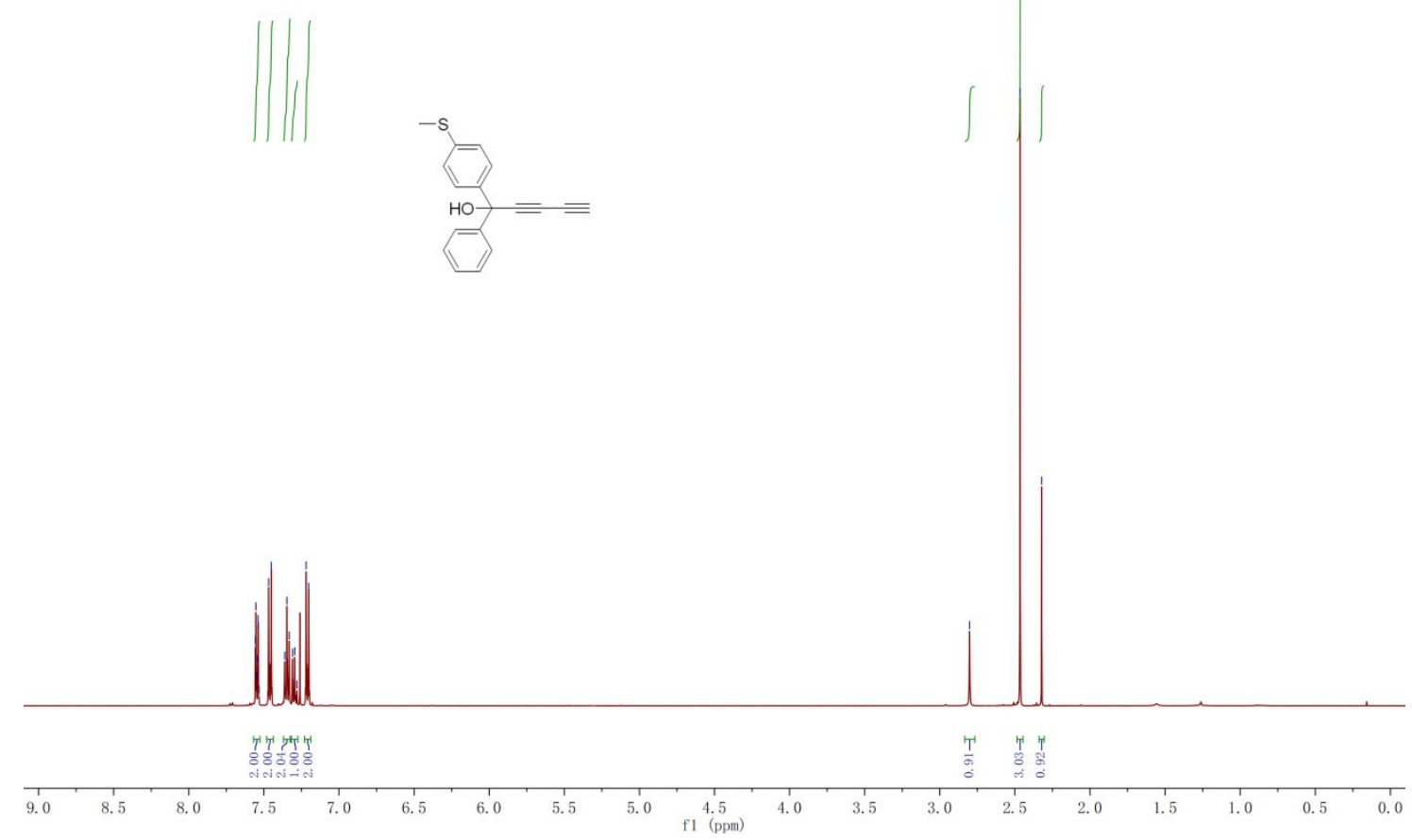

${ }^{13}$ C NMR spectrum of 9
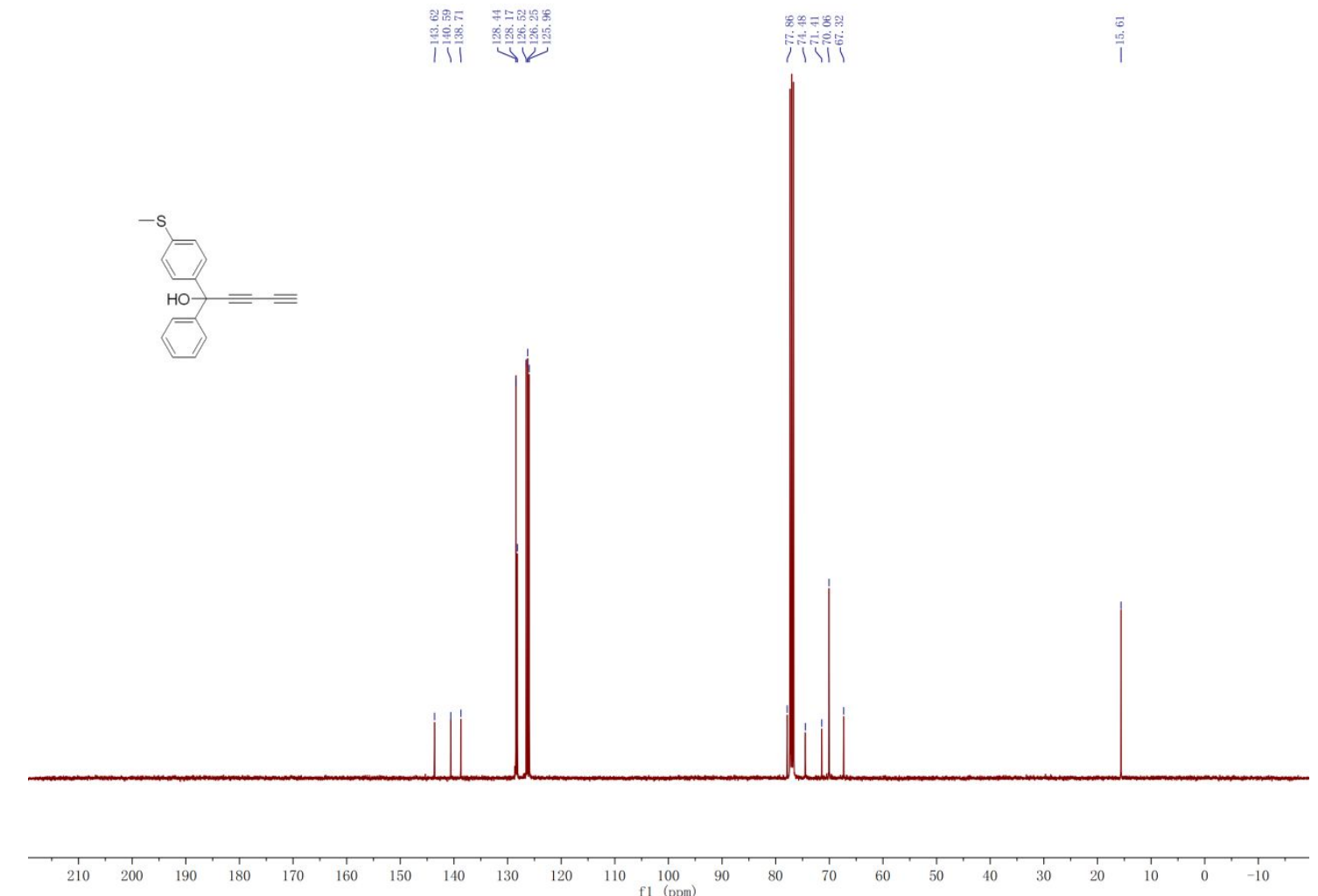


\section{${ }^{1} \mathrm{H}$ NMR spectrum of 10}

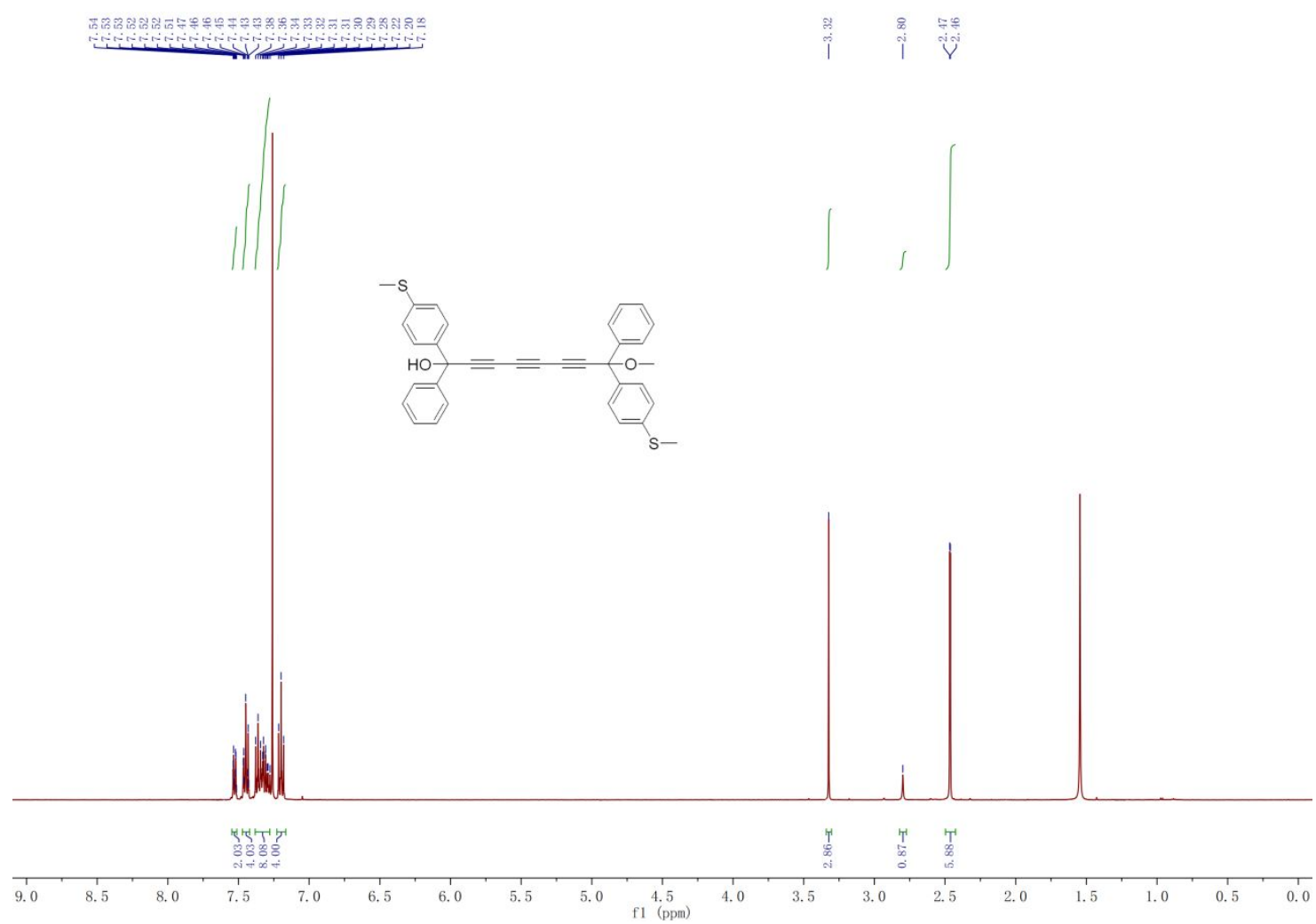

\section{${ }^{13}$ C NMR spectrum of 10}
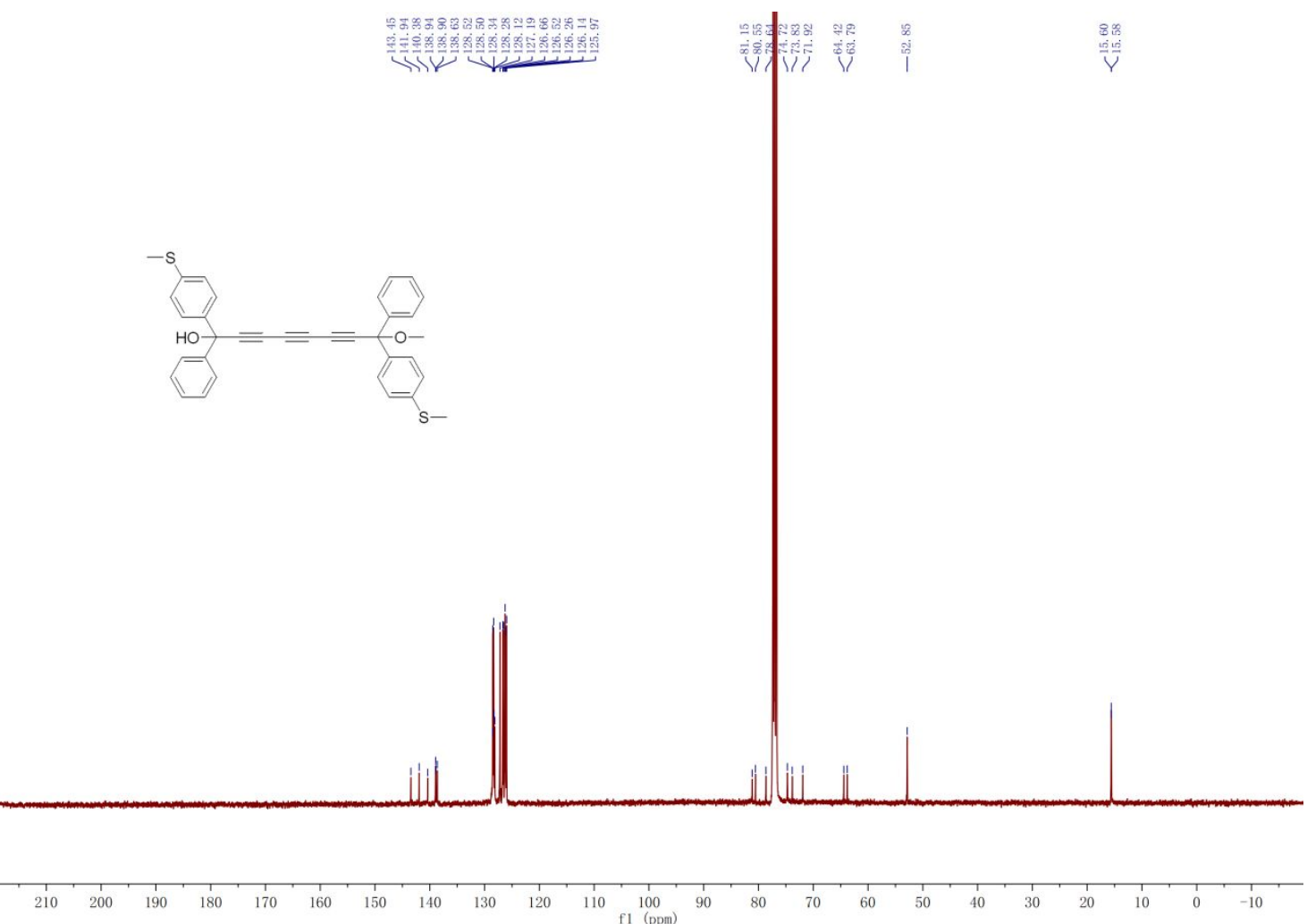


\section{${ }^{1} \mathrm{H}$ NMR spectrum of $C 8$}

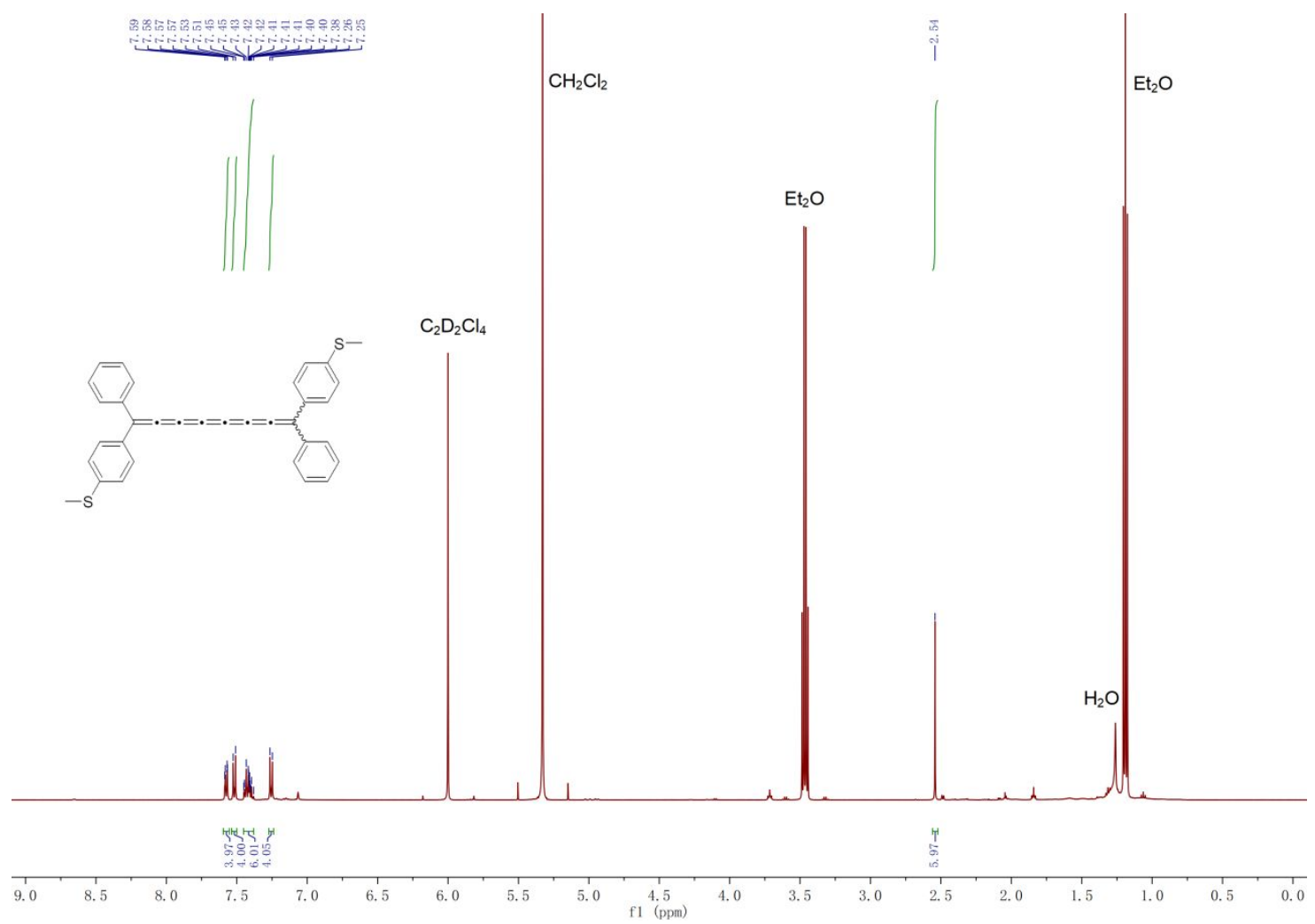

\section{${ }^{13} \mathrm{C} N M R$ spectrum of $C 8$}
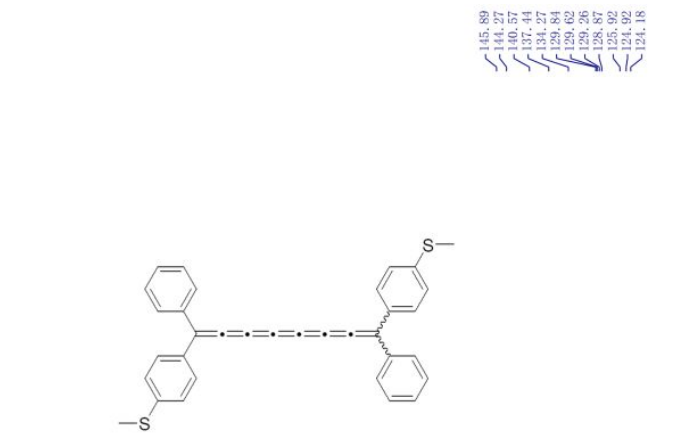

तो
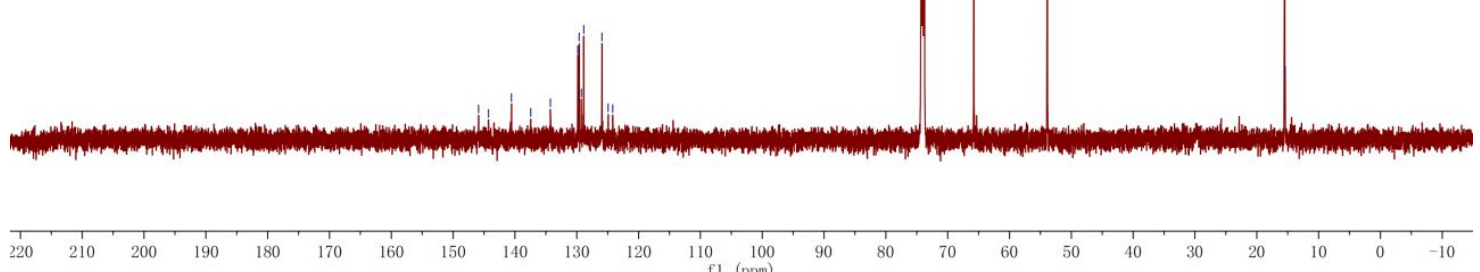


\section{References}

1. Batsanov, A. S.; Collings, J. C.; Fairlamb, lan J. S.; Holland, J. P.; Howard, J. A. K.; Lin, Z.; Marder, T. B.; Parsons, A. C.; Ward R. M.; Zhu, J. J. Org. Chem. 2005, 70, 703-706.

2. Zhang, L.-Y.; Duan, P.; Wang, J.-Y.; Zhang, Q.-C.; Chen, Z.-N. J. Phys. Chem. C 2019, 123, $5282-5288$.

3. Zang, Y.; Zou, Q.; Fu, T.; Ng, F.; Fowler, B.; Yang, J.; Li, H.; Steigerwald, M. L; Nuckolls, C.; Venkataraman, L. Nat. Comm. 2019, 10, 4482. 